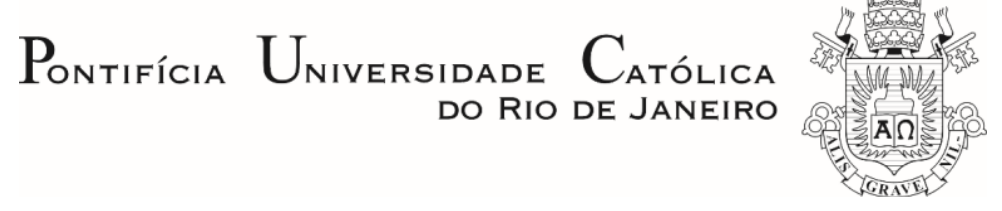

Thiago Mathias Costa

Os vocábulos autonomia e soberania nas páginas da Gazeta de Buenos-Ayres em 1811-1812

\title{
Monografia de Graduação
}

Monografia apresentada ao Departamento de História da PUC-Rio como requisito parcial para obtenção do título de Bacharel em História.

Orientador: Prof. Marco Antonio Villela Pamplona

Rio de Janeiro

Dezembro de 2016 


\section{Agradecimentos}

Aos meus pais Leila e Felipe, pelo apoio, carinho e paciência. Por toda a força dada quando decidi trocar o curso de Engenharia pelo de História.

Ao meu irmão Pedro que, apesar das brigas e implicâncias, é o meu melhor amigo.

À minha namorada Isabela, pelo amor e carinho. $E$ por ter me aturado neste final de caminho em que só sabia falar de monografia e acabei não dando a atenção que merece.

Aos meus amigos Isabelle, Leticia, Ana Carla, Bey, Alice, Carol, Malice e Luan, pelo carinho, companheirismo e apoio durante essa caminhada.

À Bianca que mais que amiga é uma irmã. Obrigado pelo carinho e apoio apesar da distância que nos separa.

Ao meu orientador Marco Antonio Pamplona, que desde 2012 me orienta. As lições aprendidas são importante parte do historiador que serei.

Aos meus colegas de História pelas conversas, debates e festas no CASOC que tanto me ajudaram nesses anos.

A todos os professores e funcionários do Departamento de História que sempre cuidaram e ajudaram ao longo da graduação.

Ao CNPq e à PUC-Rio, pelos auxílios concedidos, sem os quais este trabalho não poderia ter sido realizado. 


\section{Resumo}

Neste trabalho buscamos analisar a partir das páginas do periódico portenho Gazeta de Buenos-Ayres como os conceitos autonomia e soberania sofrem transformações em suas acepções do Antigo Regime após os acontecimentos da Revolução de Maio de 1810. Investigamos a influência deste periódico nestas transformações como principal veículo de informações dos governos formados neste período e como as próprias mudanças nas significações destes termos transformam a maneira que a Gazeta publica o seu material.

\section{Palavras Chave}

Autonomia; Soberania; Gazeta de Buenos-Ayres; Revolução de Maio; Argentina 


\section{Abstract}

In this work we seek to analyze in the pages of the Buenos Aires periodical Gazeta de Buenos-Ayres how the concepts of autonomy and sovereignty undergo changes in their meanings of the Old Regime after the events of the May Revolution of 1810. We investigate the influence of this periodical in these transformations as the main vehicle of information from the governments formed in this period and how the very changes in the meanings of these terms transform the way the Gazeta publishes his material.

\section{Key Words}

Autonomy; Sovereignty; Gazeta de Buenos-Ayres; May Revolution; Argentina 


\section{Sumário}

1. A Revolução de Maio e a fundação da Gazeta de Buenos-Ayres 6

1.1. A crise da monarquia espanhola e a invasão napoleônica 6

1.2. A Revolução de Maio de 1810 e a formação da Junta Governativa 8

1.3. A fundação da Gazeta de Buenos-Ayres

2. A Gazeta de Buenos-Ayres no ano de 1810: Principais discussões 16

2.1. Discussão sobre a convocação dos deputados a Buenos Aires 23

2.2. Recebimento da instalação da junta no Brasil e no Peru 28

2.3. Discussões sobre a instalação da junta 30

3. A Gazeta de Buenos-Ayres no ano de 1811: Principais discussões. 33

3.1. Discussões acerca da governança das Províncias. 35

3.2. Guerra contra Montevidéu 42

$\begin{array}{ll}\text { 3.3. Liberdade } & 47\end{array}$

4. Conclusão 52

5. Fontes 54

6. Referências Bibliográficas $\quad 55$ 


\section{A Revolução de Maio e a fundação da Gazeta de Buenos- Ayres}

\section{1}

\section{A crise da monarquia espanhola e a invasão napoleônica}

A situação de "acefalia do reino" que abriria caminho para a Revolução de Maio em Buenos Aires possuiu gestação no conflito entre o Rei Carlos IV e seu filho Fernando. O Motín de Aranjuez ocorrido em 19 de março de 1808, em Madri, foi uma revolta popular organizada por parte dos membros da corte espanhola que apoiavam o Príncipe. Estes desgostosos, com o primeiro ministro espanhol e com as politicas adotadas, tinham como objetivo pressionar a renuncia de Manuel Godoy e, por conseguinte, o fim do reinado de Carlos IV.

Com a queda de seu protegido e o aumento de insatisfação dos membros da corte ao seu governo o Rei abdicou em favor de seu filho. O seu decreto de abdicação como transcrito na La Gaceta de Madrid diz o seguinte:

“El Sr. Rey D. Carlos quarto se sirvió expedir el real decreto siguiente:

'Como los achaques de que adolezco no me permiten soportar por más tiempo el grave peso del gobierno de mis reinos, y me sea preciso para reparar mi salud gozar en clima más templado de la tranquilidad de la vida privada; he determinado despues de la más seria deliberación, abdicar mi corona en mi heredero y mi mui caro hijo el Principe de Asturias. Por tanto es mi leal voluntad que sea reconocido y obedecido como Rei y Señor natural de todos mis reinos y dominios. Y para que este mi real decreto de libre y espontánea abdicación tenga su exacto cumplimiento, lo comunicaréis al consejo y demás quienes corresponda. Cevallos,, 1

Dado en Aranjuez, a 19 de marzo de 1808. Yo, el Rey.- A Don Pedro

Embora em seu decreto Carlos IV culpe sua saúde para a sua abdicação, ele sabia que no momento não possuía força politica para se opor ao filho que no dia 23 de março entrou na cidade de Madri aclamado como Rei Fernando VII. Carlos

\footnotetext{
${ }^{1}$ La Gaceta de Madrid de 25 de Março de 1808
} 
IV na tentativa de conseguir reconquistar o trono buscou apoio de Napoleão Bonaparte que, graças ao Tratado de Fontainebleau ${ }^{2}$, possuía tropas em território espanhol e assim conseguir a renúncia de seu filho. Ao mesmo tempo Fernando VII também foi ao encontro do Imperador Francês em busca de legitimação de seu reinado e assim conseguir estabilidade política para governar o Império espanhol.

Planejando colocar o seu irmão José Bonaparte no poder e tornar a Espanha Estado Satélite do Império, Napoleão convidou os dois disputantes à cidade francesa de Baiona em 5 de maio de 1808 para resolver a situação do trono espanhol. Neste encontro, primeiro fez Fernando VII abdicar em nome do pai Carlos IV e depois, este abdicar em nome de seu irmão.

Com o fim da monarquia Bourbon, a subida de José I ao trono e a prisão de Fernando VII e Carlos IV iniciou-se a Guerra de Independência Espanhola (1808 1814). Diante da "acefalia do reino", constituiu-se em 25 de setembro de 1808 na região de Aranjuez, a Junta Central Gubernativa del Reino ou simplesmente Junta Central que, posteriormente, foi transferida para a cidade de Sevilha. Esta era composta pelos 35 presidentes das Juntas Supremas organizadas para resistir ao invasor francês e dizia governar no lugar e em nome de Fernando VII como depositária da soberania ${ }^{3}$. Durante seu governo a Junta organizou as Cortes do Império espanhol composta por membros tanto da península como representantes dos territórios das Américas que, desde 22 de janeiro de 1809, não eram mais considerados pela Junta colônias ou feitorias, mas membros da Monarquia espanhola. Noemi Goldman escreve que: "Las reacciones americanas al respecto fueron ambivalentes; se conjugaron la satisfacción por participar con la insastifacción por la desigualdad en el trato." " Desigualdade essa que se dava pelo número de representantes americanos convocados para as Cortes: nove, enquanto os representantes peninsulares eram trinta e cinco.

\footnotetext{
${ }^{2}$ Firmado em 27 de outubro de 1807 entre Espanha e França este acordo determinava uma invasão conjunta de Portugal e uma posterior divisão dos territórios deste entre as duas nações.

${ }^{3}$ O Dicionário da Real Academia Espanhola de 1803 define soberania como: "Alteza y poderio sobre todos".

${ }^{4}$ GOLDMAN, Noemi. Crisis Imperial, Revolución y Guerra (1806-1820). In: GOLDMAN, Noemi (Org). Nueva Historia Argentina: Tomo 3 Revolución, República, Confederación (18061852). 2 Ed. Buenos Aires: Sudamericana, 2005. p. 31.10 v.
} 
A invasão da Andaluzia por tropas francesas fez com que os membros da Junta Central fossem acusados de traição pelos espanhóis. Assim eles transferiram seus poderes ao Conselho de Regência, instalado em 29 de janeiro de 1810 em Cádiz. Esse processo de transferência de poder levou o Conselho a ter pouca legitimidade para governar tanto em território espanhol como nas Américas ${ }^{5}$.

Cabe agora analisar como esse processo de crise da monarquia espanhola foi recebido no Vice Reino do Prata, em especial na cidade de Buenos Aires.

\section{2}

\section{A Revolução de Maio de 1810 e a formação da Junta Governativa}

Durante o vice-reino o comercio exterior só acontecia entre colônia e metrópole, sendo proibido o comércio com outras potências estrangeiras. Essa situação era prejudicial para cidade de Buenos Aires que era um importante porto comercial, não apenas pelo escoamento de metais e mercadorias que vinham pelo Rio da Prata, mas pelo intenso comércio de escravos realizado no porto portenho. Não eram apenas bens que chegavam através do porto, novas ideias e escritos vindos da Europa e do resto das Américas também eram trazidos não só em formato escrito como também na fala dos viajantes e marinheiros. A declaração de Independência dos Estados Unidos em 1776, a Revolução Francesa e a Declaração dos Direitos do Homem e do Cidadão tiveram grande influência na formação da jovem burguesia crioula - descendentes de espanhóis nascidos na América. As ideias liberais surgidas após a Revolução Francesa e autores como Voltaire, Rousseau e Montesquieu foram determinantes para o pensamento da geração que participou da Revolução de Maio.

O exercício político durante o vice-reinado se dava por instituições subordinadas à Coroa espanhola que designava os funcionários destas, na maior parte espanhóis vindos da metrópole e que não possuíam nenhum vínculo com os problemas e interesses da colônia. Embora não houvesse uma divisão de classes entre os espanhóis peninsulares e os americanos, os cargos mais importantes recaiam sobre o primeiro grupo. A burguesia crioula, fortalecida pelo comércio e com novas ideias, esperava uma oportunidade para ter maior participação na

\footnotetext{
${ }^{5}$ Ibidem, p. 30.
} 
politica e esta oportunidade surgiu com as Invasões Inglesas (1806 - 1807) ao Vice-Reino.

As tropas inglesas lideradas por Home Pophan e William Carr Beresford desembarcaram em Buenos Aires em 25 de junho de 1806 e, depois de uma parca tentativa de defesa por parte das tropas coloniais, conseguiram a capitulação da cidade em dois dias. Essa invasão se deu tanto por motivos militares quanto econômicos, afinal a cidade possuía uma posição geográfica estratégica para a Inglaterra expandir o seu poderio comercial na região além de deixar o Império Espanhol em uma posição fracamente guarnecida.

Nesse ínterim o Vice Rei Rafael de Sobremonte se retirou da cidade rumo a Córdoba levando consigo o tesouro real, que foi entregue aos ingleses no dia $5 \mathrm{de}$ julho e posteriormente enviado a Grã-Bretanha. Os esforços de reconquista da cidade couberam ao capitão de fragata Santiago de Liniers, com o apoio do governador da cidade de Montevidéu, Pascual Huidobro, e das milícias organizadas pela população tanto dentro quanto fora da cidade. Após quarenta e seis dias desde o desembarque das tropas inglesas em Quilmes, ocorreu a sua rendição frente às forças portenhas ${ }^{6}$.

Com a decisão do Vice Rei de entregar as finanças da colônia aos estrangeiros durante a ocupação, convocou-se um Cabildo Aberto no dia 14 de agosto para discutir as ações deste. Decidiu-se colocar nas mãos de Liniers o poderio militar da cidade e entregou-se ao presidente da Audiência o poder de governo. Liniers, sabendo que apenas as tropas de linha não seriam suficientes caso houvesse outra tentativa de invasão da cidade, decidiu converter em tropas oficiais as forças voluntárias que haviam lutado na reconquista. Em uma proclamação, no dia 6 de setembro, criou as milícias urbanas da cidade de Buenos Aires:

“(...)Vengan, pues, los invencibles cántabros, los intrépidos catalanes, los valientes asturianos y gallegos, los temibles castellanos, andaluces y aragoneses; en una palabra, todos los que llamándose españoles se han hecho dignos de tan glorioso nombre. Vengan, y unidos al esforzado, fiel e inmortal americano, y a los demás habitadores de este suelo, desafiaremos a esas aguerridas huestes enemigas que, no contentas con causar la desolación de las ciudades y los campos del

\footnotetext{
${ }^{6}$ Ibidem, p. 33 .
} 
mundo antiguo, amenazan envidiosas invadir las tranquilas y apacibles costas de nuestra feliz América. ",

Três dias depois proclamou-se uma ordem para que aqueles que fossem voluntários a estes corpos se apresentassem ao forte da cidade para organizar os batalhões, nomearem seus comandantes - que seriam decididos por seus comandados - e decidir seus uniformes. A ordem de Liniers pode ser vista no trecho abaixo:

"vengo en convocarlos por medio de ésta, para que concurran a la Real Fortaleza, los días que abajo irán designados, a fin de arreglar los batallones y compañías, nombrando los comandantes y sus segundos, los capitanes y sus tenientes a voluntad de los mismos cuerpos; a los cuales presentaré en aquel acto un diseño del uniforme que precisamente deben usar, si ya no le tuvieren elegido.

(...) Ninguna persona en estado de tomar las armas dejará de asistir sin justa causa á la citada reunión, so pena de ser sospechosa y notada de incivismo, quedando en tal caso sujetos á los cargos que deban hacérseles."

Como a escolha dos comandantes era realizada de modo democrático dentro dos corpos de milícia, muitos crioulos ascenderam politicamente dentro do sistema organizacional do Vice-Reino.

A decisão de Liniers mostrou-se acertada quando no ano seguinte os ingleses novamente tentaram tomar a cidade de Buenos Aires e foram rechaçados pelas forças defensoras. Após a vitória, o Cabildo se reuniu e decidiu retirar o Vice-Rei Sobremonte do cargo que, frente à ameaça estrangeira, novamente, havia fugido para o interior. Em seu lugar subiu ao poder Liniers, reconhecido como herói durante as Invasões Inglesas.

Porém o governo de Liniers começou a sofrer sérios questionamentos após a chegada das noticias das Abdicações de Baiona e o encontro com um representante de Napoleão Bonaparte que pretendia que o Vice-Reino reconhecesse o governo de José Bonaparte. Embora tenha sofrido pressão do Cabildo e do governador da cidade de Montevidéu Francisco Xavier de Elío, Liniers se manteve no poder com o apoio das milícias, jurando fidelidade à Junta Central de Sevilha então reconhecida como a depositária da soberania. Esta, no

\footnotetext{
${ }^{7}$ Proclama de Santiago de Liniers y Bremond para la creación de los Cuerpos Urbanos destinados a la defensa de Buenos Aires, 06 de Setembro de 1806.

${ }^{8}$ Orden de Santiago de Liniers y Bremond para la convocatoria de las Milicias Urbanas, 09 de Setembro de 1806
} 
entanto, acabou substituindo-o em 1809 por D. Baltasar Hidalgo Cisneros, que foi o último Vice-Rei do Prata.

Em 14 de maio de 1810 chegaram ao porto de Buenos Aires os periódicos que traziam a notícia da queda da Junta Central por tropas francesas e formação do Conselho de Regência em Cádiz. Com a queda da Junta, também o Vice-Rei Cisneros perdia sua legitimidade frente ao governo. Em 18 de maio tentando acalmar os ânimos o Vice-Rei fez uma proclamação onde reafirmou governar em nome de Fernando VII como mostra o seguinte trecho:

"Encargado de la Autoridad Suprema de conservar intactos y tranquilos estos dominios, he dedicado á tan justo, y tan interesante objeto todos mis desvelos y fatigas. Nada he omitido de cuanto he creído conducente, al desempeño de tan elevada confianza: vosotros sois testigos de que no me dispenso una alabanza á que no tenga justos y conocidos derechos; pero ni estos, ni la general benevolencia que os debo, y a la que siempre viviré agradecido, me dispensan del deber que me he impuesto de que en el desgraciado caso de una pérdida total de la Península, y falta del Supremo Gobierno, no tomará esta Superioridad determinación alguna que no sea previamente acordada en unión de todas las representaciones de esta Capital a que posteriormente se reúnan las de sus Provincias dependientes, entre tanto que de acuerdo con los demás Virreynatos reestablece una representación de la Soberanía del Sr. Don Fernando VII." "

O apelo de Cisneros não foi ouvido e, em 22 de maio, organizou-se um outro Cabildo Aberto onde debateu-se a legitimidade do governo e da autoridade do Vice-Rei. O princípio da retroversão da soberania determinava que, na ausência de um monarca legitimo ou de uma instituição com legitimidade para governar, o poder voltaria ao povo e este teria direito de formar um novo governo. No dia 23 o Cabildo decidiu por afastar Cisneros e criar uma Junta Governativa em nome de Fernando VII:

“(...)hecha la regulación con el más prolijo examen, resulta, de ella, a pluralidad con exceso, que el Exmo. Señor Virrey debe cesar en el mando, y recaer este provisionalmente en el Exmo. Cabildo, con voto decisivo el caballero Síndico Procurador general, hasta la erección de una Junta que ha de formar el mismo Exmo. Cabildo en la manera que estime conveniente; "10

\footnotetext{
${ }^{9}$ Procalma del 18 de Mayo de 1810 apud CORBELINNI, Enrique. La Revolución de Mayo Tomo II. Buenos Aires: Lajouane, 1950. p. 20.

${ }^{10}$ Actas capitulares desde el 21 hasta el 25 de Mayo de 1810, en Buenos Aires.
} 
Apesar da breve tentativa de resistir aos mandos do Cabildo, Cisneros acabou renunciando em 25 de maio quando assumiu a Primeira Junta de Governo de Buenos Aires. Seu regulamento dizia que caberia ao Cabildo controlar a atividade dos "vocales" e à Junta nomear os seus membros em caso de vacância por qualquer motivo. A primeira Junta organizou-se da seguinte maneira:

\title{
Presidente:
}

Cornelio Saavedra

\author{
Vocales \\ Dr. Manuel Alberti \\ Cnel. Miguel de Azcuénaga \\ Dr. Manuel Belgrano \\ Dr. Juan José Castelli \\ Domingo Matheu \\ Juan Larrea
}

\section{Secretarios:}

Dr. Juan José Paso

Dr. Mariano Moreno

Assim que assumiu a Junta convocou deputados do interior para se reunirem em Buenos Aires para decidirem os rumos a serem tomados pelas províncias do Prata. Noemi Goldmam analisa esse primeiro movimento do novo governo da seguinte maneira:

"Es así como en sus relaciones con las demás partes de Virreinato, las nuevas autoridades siguieron la doctrina de 22 de mayo, al invitar los pueblos del Interior a participar de las deliberaciones de Buenos Aires, en calidad de nuevos titulares legítimos del poder. La circular de la Primera Junta de gobierno convocó a las ciudades interiores, pero encargó a sus Cabildos la elección de sus diputados. De modo la representación es entregada a la ciudad de la tradición 
hispanocolonial y dentro de ella a la 'parte principal y más sana del vecindario'."11

A fundação da Gazeta de Buenos-Ayres, em 02 de junho, como veículo utilizado para transmitir tanto as ordens da Junta como também as discussões sobre a política tomada pelo governo, foi outra maneira de buscar estreitar o relacionamento entre a cidade portenha e aquelas do interior.

\section{3}

\section{A fundação da Gazeta de Buenos-Ayres}

Antes de analisar seu conteúdo cabe uma breve apresentação deste periódico. Publicada entre 02 de junho de 1810 e 12 de setembro de 1821, a Gazeta de Buenos-Ayres foi o primeiro periódico a circular após a Revolução de Maio. Fundada pela Primeira Junta de Governo, a Gazeta defendia os valores da Junta de Governo e dos ideais revolucionários de 1810 sendo instrumento de propagação de suas ideias e de seu projeto político pela região da cidade de Buenos Aires.

Durante o tempo que circulou teve um total de 531 edições regulares publicadas: 72 números entre 1810-1811; 133 entre 1811-1814; 86 entre 18151816; 169 entre 1817-1820; e 71 entre 1820-1821. Além das publicações regulares publicou-se uma grande quantidade de gazetas extraordinárias. Todos se encontram à disposição para consulta no site da Biblioteca Nacional da Argentina.

Nos onze anos em que a Gazeta foi publicada muitos editores passaram por sua redação: Mariano Moreno - advogado, jornalista e político argentino, teve um papel decisivo na Revolução de Maio, que conduziu à independência das Províncias Unidas do Rio da Prata -, desde a sua fundação até 20 de dezembro de 1810; Deán Funes - político e eclesiástico argentino, reitor da Universidade de Córdoba, jornalista e escritor foi defensor da Revolução de Maio que tornou-se membro e diretor político da Junta Grande até março de 1811; Pedro José Agrelo advogado e político argentinos destacou-se, entre outras coisas, por ser presidente da Assembleia Constituinte de 1813 e autor do projeto da Constituição Argentina

11 GOLDMAN, Noemi. Crisis Imperial, Revolución y Guerra (1806-1820). In: GOLDMAN, Noemi (Org). Nueva Historia Argentina: Tomo 3 Revolución, República, Confederación (18061852). 2 Ed. Buenos Aires: Sudamericana, 2005. p. 42.10 v. 
daquele ano. Desde 18 de março até 5 de outubro de 1811; Vicente Pazos Silva político, escritor, jornalista e religioso, esteve envolvido na política Argentina e Boliviana - e Bernardo Monteagudo - advogado, político, jornalista, militar e revolucionário argentino, que participou dos processos de independência no Rio da Prata, Chile e Peru - até 8 de outubro de 1812. Nicolás Herrera - político e jurista da região do Rio da Prata -, nela contribuiu até abril de 1815. Camilo Henríquez - sacerdote, escritor e político chileno, nela escreveu vários ensaios, incluindo a Proclamação de Quirino Lemáchez, onde promoveu a independência do Chile e a liberdade social até novembro do mesmo ano. Julián Álvarez advogado e político, dela participou até abril de 1820 e Manuel Antonio Castro advogado e político argentino, governador Prefeito de Córdoba durante o período das Províncias Unidas do Rio da Prata -, nela ficou até a sua extinção, em 12 de setembro de 1821 .

Logo nas primeiras linhas de sua edição inaugural a Gazeta, na condição de instrumento da Junta Governativa, deixava claras as suas intenções para o "Pueblo" da cidade de Buenos Aires:

"Desde el momento en que un juramento solemne hizo responsable á esta Junta del dedicado cargo que el Pueblo se ha dignado confiarle, ha sido incesante el desvelo de los individuos que la forman, para llenar las esperanza de sus conciudadanos." $" 12$

Neste mesmo número a Junta expõe os seus motivos para a criação da Gazeta de Buenos-Ayres e qual o seu propósito:

"Para el logro de tan justos deseos ha resuelto la Junta que salga á luz un nuevo periódico semanal con el título de Gazeta de Buenos Ayres, el qual sin tocar los objetos que tan dignamente se desempeñan en el semanario de comercio, anuncie al público las noticias exteriores é interiores que deban mirarse con algún interés. En el se manifetarán igualmente las discusiones oficiales de la Junta con los demas Xefes y Gobiernos, el estado de la Real Hacienda, y medidas económicas para su mejora y una franca comunicación de los motivos que influyan

\footnotetext{
${ }^{12}$ Gazeta de Buenos-Ayres número 01, 02 de Junho de 1810
} 
en sus principales providencias, abrirá la puerta á las advertencias que desea qualesquiera que pueda contribuir con sus luces á la seguridad del acerto."13

O papel da Gazeta de Buenos-Ayres, como esclareceu Mariano Moreno no trecho acima, não era apenas um veículo de noticias, mas também um periódico político que tinha como proposta expor em suas páginas as discussões sobre o governo da Junta. Além disso, promoveu a publicação de outros escritos além daqueles de seus editores, de tal modo que pôde contribuir para formação de um governo que lograsse acerto a partir das luzes.

Cabe agora analisar de que modo este periódico influenciou o vocabulário político da época, com ênfase nas discussões sobre autonomia e soberania, nesse momento de transição e experimentação política que os povos do antigo ViceReino do Prata estavam vivendo.

${ }^{13}$ Idem 


\section{A Gazeta de Buenos-Ayres no ano de 1810: Principais discussões}

Para analisar como os vocábulos autonomia e soberania aparecem na Gazeta de Buenos-Ayres nos anos de 1810 e 1811 investigaremos trechos selecionados de diversos números do periódico nos anos citados e a partir destes faremos uma análise mais minuciosa do vocabulário utilizado. Neste capítulo analisaremos o ano de 1810 e no seguinte o ano de 1811.

Dividiremos os trechos selecionados em três temas transversais às discussões do vocabulário político que queremos apresentar. São estes: a convocação dos deputados da província a cidade de Buenos Aires, o debate sobre a instalação e legitimidade da Junta Provisória e o recebimento da instalação da Junta portenha no resto do continente. Antes de começar a análise, porém, devemos discutir a importância do periódico na província e qual a proposta que seus fundadores tinham para esta empresa.

João Paulo Garrido Pimenta, em seu trabalho Estado e Nação no fim dos Impérios Ibéricos no Prata (1808-1828), apresenta certos critérios para considerar se um periódico possuía grande circulação e, por consequência, se tinha relevante importância na região que circulava. Os critérios apresentados por Pimenta são os seguintes:

"Em primeiro lugar, pela duração de sua publicação. A longevidade de um periódico em um contexto (ainda que em progressivo crescimento) no qual a maioria das publicações durava poucos meses ou semanas e não passava de seus números iniciais, significa que ele era vendido o suficiente para se perpetuar, portanto que ele era significativamente lido. Nos casos em que o periódico contava com algum tipo de subsídio oficial, isto poderia garantir melhor distribuição. Em segundo lugar, impõe-se atentar para as referências recíprocas entre periódicos. Seja por meio de notícias extratadas ou de polêmicas travadas, o fato de um periódico ser referido por outro significa que aquele era lido, e talvez incomodasse tanto em debates políticos que merecia ser contestado. É ainda razoável supor que o incômodo seria maior se o periódico contrário tivesse boa circulação. Neste ponto, vale uma especial atenção para os casos em que os periódicos de outros países referem-se reciprocamente, pois neste caso fica atestada uma circulação espacialmente muito abrangente. Um terceiro ponto diz respeito à publicação de 
anúncios. Geralmente curtos, procurando venda, troca e compra de mercadorias, serviços e imóveis, eram uma constante em vários periódicos. Dessa forma, presume que só se anunciaria em um espaço que fosse significativamente lido para se poder esperar uma resposta. Um último ponto importante, ainda que a sua utilização exija maiores cuidados, diz respeito à participação de leitores por meio de comunicados. Embora não se possa ter certeza de que as cartas enviadas para publicação fossem de fato escritas por leitores (eram na maioria das vezes subscritas por siglas ou pseudônimos), é possível presumir uma relação entre o seu número em determinado periódico e uma considerável circulação deste. "14

A partir destes critérios e das informações apresentadas sobre a Gazeta de Buenos-Ayres no capítulo anterior, podemos afirmar que a Gazeta foi um periódico de grande relevância na sua área de circulação. Ao analisar cada critério e as informações do periódico, destacamos as seguintes informações:

Duração de sua publicação - a Gazeta durou 11 anos e publicou 531 edições regulares. Devemos atentar que por ser o veículo oficial da Junta tinha o apoio desta;

Referências recíprocas entre periódicos - podemos vê-la sendo mencionada em periódicos do Brasil, Montevidéu e de outras regiões da América Ibérica;

Publicação de anúncios e participação de leitores por meio de comunicados eram extremamente comuns, com pelo menos um dos dois critérios aparecendo nas edições publicadas.

Bastante comum nas publicações da Gazeta de Buenos-Ayres em 1810 foi a exaltação por parte desta ao "Pueblo" portenho e aos demais "pueblos" que decidiram apoiar a Junta Governativa e enviaram seus deputados à capital. Esta estratégia tinha como efeito manter a felicidade dos detentores da soberania, pois os membros do governo sabiam assim como haviam retirado o antigo Vice-Rei do poder o mesmo poderia acontecer com a Junta. Podemos ler no seguinte fragmento da edição número vinte e dois o modo como se dava esse elogio:

"Es justo que los pueblos esperen todo bueno de sus dignos representantes; pero también es conveniente que aprendan por si mismos lo que es debido a sus intereses y derechos. Felizmente se observa en nuestras gentes, que sacudido antiguo adormecimiento manifiestan un espíritu noble dispuesto para grande cosas, y capaz de qualesquier sacrificios, que conduzcan á la consolidación del bien general. Todos discurren ya sobre la felicidad pública, todos experimentan cierto presentimiento, de que van á alcanzarla prontamente; todos juran allanar

\footnotetext{
${ }^{14}$ PIMENTA, João Paulo. Estado e Nação no fim dos impérios ibéricos no Prata (1808-1828). São Paulo: Hucitec, 2006. p. 69-70.
} 
con su sangre los embarazos, que se opongan á su consecución; pero quizá no todos conocen, en que consiste esa felicidad general á que consagran sus votos, y sacrificios; y desviados por preocupaciones funestas de los verdaderos principios, á que esta vinculada la prosperidad de los estados, corren el riesgo de muchos pueblos, á quienes una cadena de la mas pesada esclavitud sorprendió en medio del placer, con que celebraban el triunfo de su naciente libertad." 15

Neste parágrafo vemos uma reflexão do editor sobre o papel dos "pueblos" na manutenção do novo governo. Para ele, os "pueblos" deveriam acreditar em seus representantes, mas também tinham que buscar conhecer os seus direitos. No trecho há uma defesa a estes "pueblos", pois para o autor estavam lutando e se sacrificando para a consolidação do bem e da felicidade geral.

Nota-se uma exaltação por parte dos editores à própria Junta e ao fato dela ter sido generosa em relação aos "pueblos", assim atraindo mais simpatizantes à causa portenha, como pode ser visto no trecho a seguir da edição número dezesseis:

"Nada se presenta mas lisongero á um gobierno enpeñado sinceramente em la felicidad de los pueblos, que ver a estos agitados em las questiones $e$ ocurrencias, que tocan directamente a la comunidad. El déspota que teme el decubrimiento de su conducta, procura sofocar en los hombres hasta el deseo de examinarla, y prefiere sepultarse em los abismos de que su propria ignorancia lo rodea, antes que premitira aquella francas discusiones, que prodeucen los recursos consiguientes á una general ilustracion. Por fortuna la confianza de los que gobiernan, y de los que son gobernados forma la base mas firme del nuevo gobierno." 16

Excetuando-se os dois últimos números do ano de 1810, a Gazeta teve como editor o primeiro secretário da Junta Provisória Mariano Moreno que traduziu a primeira edição americana do Contrato Social de Rousseau. Advogado, o crioulo Moreno tem contato com as ideias iluministas durante seus estudos na Universidade de Chuquisaca. Um dos importantes revolucionários que apoiaram a Revolução de Maio, suas ideias a favor de um governo central forte, livre comércio, igualdade e educação secular irão aparecer em seus escritos, inclusive aqueles publicados pela Gazeta.

\footnotetext{
${ }^{15}$ Gazeta de Buenos-Ayres número 22, 01 de novembro de 1810, p. 3.

${ }^{16}$ Gazeta de Buenos-Ayres número 16, 20 de setembro de 1810, p. 1.
} 
Analisemos por partes a Ordem da Junta escrita por Mariano Moreno que abre o primeiro número da Gazeta para entender os motivos por trás da criação do periódico.

"Orden de la Junta

Desde el momento en que un juramento solemne hizo responsable á esta Junta del delicado cargo que el Pueblo se ha dignado confiarle, ha sido incesante el desvelo de los individuos que la forman para llenar las esperanzas de sus conciudadanos. Abandonados casi enteramente aquellos negocios á que tenían vinculada su subsistencia, contraidos al servicio del público, con una asiduidad de que se han visto aquí pocos exemplos, diligentes en proporcionarse todos los medios que puedan asegurarles el acierto; vé la Junta con satisfaccion que la tranquilidad de todos los habitantes acredita la confianza con que reposan en el zelo y vigilancia del nuevo Gobierno.

Podría la Junta reposar igualmente en la gratitud con que publicamente se reciben sus tareas; pero la calidad provisoria de su instalacion redobla la necesidad de asegurar, por todos los caminos, el concepto debido á la pureza de sus intenciones.(...)"17 (negrito meu)

Neste primeiro fragmento podemos perceber que a Junta Provisória condiciona o seu projeto ao voto de confiança que "El Pueblo", como depositário da soberania, dava ao novo "Gobierno”. Podemos perceber também que a própria Junta sabia de seu caráter provisório, pois governaria até a decisão dos deputados que decidiriam a melhor maneira de manter a autonomia das províncias e de que maneira iria governá-las.

Antes de passar para o próximo trecho da Ordem analisaremos melhor os vocábulos Pueblo/pueblo/pueblos que, neste primeiro número da Gazeta já demostram uma acepção diferente da utilizada no Antigo Regime.

O Dicionário da Real Academia do ano de 1803 define o vocábulo de três maneiras distintas que são: "El lugar, ó ciudad que está poblado de gente"18; "El conjunto de gentes que habitan el lugar" alguna ciudad, o plabacion, á distincion de los nobles" ${ }^{20}$. O termo, "pueblo" como fica claro na acepção dada pelo dicionário, tinha sentido social e/ou

\footnotetext{
${ }^{17}$ Gazeta de Buenos-Ayres número 01, 07 de junho de 1810, p. 1.

${ }^{18}$ Diccionario de la Real Academia Española. Diccionario de la lengua castellana compuesto por la Real Academia Española, reducido a un tomo para su más fácil uso. Quarta edición. Madrid: Viuda de Ibarra, 1803. p 695.

${ }^{19}$ Idem.

${ }^{20}$ Idem.
} 
geográfico sendo utilizado para caracterizar locais povoados, a sua população, e por fim aqueles que não são nobres, ou seja, a plebe. Quando utilizado no plural "pueblos" pode ter dois significados: o primeiro como plural do termo "pueblo" e o outro como Noemi Goldman e Gabriel Di Meglio explicam no Diccionario politico y social de mundo iberoamericano, que era

“(...) propia de la tradición hispánica: como comunidades locales naturales cuyas obligaciones consistían en el «amor del Soberano», el respeto a las leyes y la conservación del orden público. Los pueblos a su vez se distinguían étnica y culturalmente según fuesen españoles o indigenas (pueblo de indios).

Os acontecimentos do Cabildo Abierto de 22 de maio de 1810 que determinaram a retroversão da soberania do monarca aos "pueblos" que voltaram a ser os depositários do poder político influenciaram a mudança do vocábulo "pueblo" que passou a ter também, além dos seus significados anteriores, um caráter político. Quando Mariano Moreno utiliza “el Pueblo" ele se refere àqueles sob a Junta Provisória que são os depositários da soberania e que têm o poder de escolher a forma de governo, ou seja, não é todo "el pueblo", pois não eram todos que tinham direitos políticos garantidos neste momento.

Continuando com a análise do editorial temos o seguinte trecho:

"Una exâcta noticia de los procedimientos de la Junta: una continuada comunicacion pública de las medidas que acuerde para consolidar la grande obra que se há principado, una sincera y franca manifestación de los estorbos que se oponen al fin de su instalación y de los medios que adopta para allanarlos, son un deber en el Gobierno provisorio que exerce, y un principio para que el Pueblo no resfrie en su confianza, ó deba culparse a si mismo sino auxîlia con su energía y avisos á quienes nada pretenden sino sostener con dignidad los derechos del Rey y de la Patria, que se le han confiado. El Pueblo tiene derecho á saber la conducta de sus Representantes, y el honor de estos se interesa en que todos conozcan la exêcracion con que miran aquellas reservas y misterios inventados por el poder para cubrir los delitos.(...)"22 (negrito meu)

21 GOLDMAN, Noemi; MEGLIO, Gabriel Di. Pueblo. Argentina - Río de la Plata. In: SEBASTIÁN, Javier Fernández (Org.). Diccionario político y social del mundo iberoamericano. La era de las revoluciones, 1750-1850. Madrid: Fundación Carolina, Sociedad Estatal de Conmemoraciones Culturales, Centro de Estudios Políticos y Constitucionales, 2009, p. 11511162.

${ }^{22}$ Gazeta de Buenos-Ayres número 01, 07 de junho de 1810, p. 2. 
Percebemos que a Junta deixava clara a necessidade de manter uma comunicação com a população da província, pois apenas dessa maneira conseguiria manter o apoio desta ao seu governo. Claro está o caráter autônomo desta, embora não independente, já que tinha como dever determinado pelo "el Pueblo" "sostener con dignidad los derechos del Rey y de la Patria, que se le han confiado. ${ }^{, 23}$.

Por fim, no último fragmento selecionado, o editor mostra o porquê de criar a Gazeta de Buenos-Ayres e qual o seu papel como periódico oficial da Junta de Buenos Aires.

"Para el logro de tan justos deseos ha resuelto la Junta que salga á luz un nuevo periódico semanal, con el título de Gazeta de Buenos-Ayres, el qual sin tocar los objetos que tan dignamente se desempañan en el semanario del comercio, anuncie al público las noticias exteriores e interiores que deban mirarse con algún interés. En él se manifestarán igualmente las discusiones oficiales de la Junta con los demas Xefes y Gobiernos, el estado de la Real Hacienda, y medidas económicas para su mejora y una franca comunicacion de los motivos que influyan en sus principales providencias, abrira la puerta á las advertencias que desea dar qualesquiera que pueda contribuir con sus luces a la seguridad del acierto.

La utilidad de los discursos de hombres ilustrados que sostengan y dirijan el patriotismo y fidelidad, que tan heroicamente se ha desplegado; nunca es mayor que cuando el choque de las opiniones pudiera envolver en tinieblas aquellos principios; que los grandes talentos pueden únicamente reducir á su primitiva claridad; y a la Junta, á mas de incitar ahora generalmente á los sabios de estas Provincias para que escriban sobre tan importantes objetos, los estimulará por otros medios que les descubran la confianza que ponen en sus luces y en su zelo.

Todos los escritos relativos á este recomendable fin se dirigirán al Señor Vocal Dr. D. Manuel Alberti, quien cuidará privativamente de este ramo, agregándose por la Secretaría las noticias oficiales cuya publicacion interese. El Pueblo recibirá esta medida como una demostración sincera del aprecio que hace la Junta de su confianza; y de que no anima otro espiriitu sus providencias que el deseo de asegurar la felicidad de estas Provincias.=Buenos-Ayres 2 de Junio de $1810=$ D. Marianao Moreno, Secretario ${ }^{, 24}$ (negrito meu).

Podemos destacar duas ideias importantes nesta passagem. A primeira diz respeito novamente ao caráter autônomo do governo ao ter como objetivo publicar "las discusiones oficiales de la Junta con los demas Xefes y Gobiernos, el estado de la Real Hacienda, y medidas económicas (...)",25 , visto que as discussões com outros poderes da região e além, durante o vice-reinado, eram feitas por oficiais da

\footnotetext{
${ }^{23}$ Idem.

${ }^{24}$ Gazeta de Buenos-Ayres número 01, 07 de junho de 1810, p.3.

${ }^{25}$ Idem.
} 
Coroa espanhola, e as medidas econômicas ocorriam da mesma maneira. Esta sentença destacada também demonstra a preocupação de dar satisfação de todos os movimentos da Junta ao Pueblo.

A segunda tem relação com a importância do Iluminismo para os ilustrados da cidade de Buenos Aires e da "La utilidad de los discursos de hombres ilustrados que sostengan y dirijan el patriotismo y fidelidad, que tan heroicamente se ha desplegado; ${ }^{, 26} \mathrm{O}$ editor solicitava que os sábios da província escrevessem ao periódico com críticas, pois as luzes da razão e o zelo destes patriotas iriam assegurar a felicidade das províncias. Apesar deste apelo, todo escrito primeiramente seria analisado por um membro do governo, neste caso D. Manuel Alberdi, antes de ser enviado para publicação.

Cabe aqui um breve comentário acerca do vocábulo "patriotismo". Diferentemente da utilização atual, nesse período, ele não é sinônimo do termo nação. Durante o século XIX o termo pátria tinha como significado "El lugar, ciudad, ó pais en que se ha nacido. "27. Quando o editor chama os ilustrados de patriotas, não há nenhum sentimento de nacionalismo em sua fala, mas sim o de amor por seu local de nascimento.

A importância dada por Moreno à Ilustração e as Luzes pode ser melhor entendida ao ler o seguinte trecho, retirado do editorial, que tem como título: "Sobre la libertad de escribir". Nele o autor defende a liberdade de discurso e demonstra o seu desejo que os "pueblos" possam se libertar das "opiniões velhas" e se abram para as Luzes e a Ilustração.

"Desengañemonos al fin, que los pueblos yacerán en el embrutecimiento mas vergonzoso, si no se dá una absoluta franquicia y libertad para hablar en todo asunto que no se oponga en modo alguno á las verdades santas de nuestra augusta Religion, y las determinaciones del Gobierno, siempre dignas de nuestro mayor respeto. Los pueblos correrán de error en error, y de preocupación en preocupación, y harán la desdicha de su exîstencia presente y sucesiva. No se adelantarán las artes, ni los conocimientos útiles, porque no teniendo libertad el pensamiento, se seguirán respetando los absurdos que han consagrado nuestros padres, y ha autorizado el tiempo e la costumbre.

\footnotetext{
${ }^{26}$ Idem.

${ }^{27}$ Diccionario de la Real Academia Española. Diccionario de la lengua castellana compuesto por la Real Academia Española, reducido a un tomo para su más fácil uso. Quarta edición. Madrid: Viuda de Ibarra, 1803. p 631.
} 
Seamos una vez, ménos partidarios de nuestras envejecidas opiniones; tengamos menos amor proprio; dese acceso á la verdad, y á la introducción de las luces y de la ilustración: no se reprima la inocente libertad de pensar en asuntos de interese universal; no creamos que con ella se atacará jamás impunemente al mérito y la virtud, porque hablando por si mismos en su favor, y teniendo siempre por arbitro imparcial al pueblo, se reducirán á polvo los escritos de los que indignamente osasen atacarles. La verdad, como la virtud tienen en sí mismas su mas incontestable apología; à fuerza de discutirlas y ventilarlas aparecen en todo su explendor y brillo: si se oponen restricciones al discurso, vegetará el espíritu como la materia y el error, la mentira, la preocupación, el fanatismo y el embrutecimiento, harán la divisa de los pueblos, y causarán para siempre su abatimiento, su ruina y su miseria. ${ }^{, 28}$

\subsection{Discussão sobre a convocação dos deputados a Buenos Aires}

O Vice-Reino do Prata antes de sua dissolução era dividido em oito intendencias $^{29}: 1$ - intendência de Buenos Aires, cuja capital possui o mesmo nome, que engloba, entre outras, as cidades de Montevideo, Corrientes e Maldonado; 2 - intendência de Córdoba del Tucumán, cuja capital é Córdoba, que engloba, entre outras, as cidades de Mendonza e San Juan; 3 - intendência de Salta del Tucumán, cuja capital é Salta, que engloba, entre outras, as cidades de Santiago de Estero e San Miguel de Tucumán; 4 - intendência do Paraguai, cuja capital é Asunción, que engloba, entre outras, as cidades de Villarica e Villa Real; 5 - intendência de Potosí, cuja capital possui o mesmo nome, que engloba, entre outras, as cidades de Parco, Chicas e Atacama; 6 - intendência de La Paz, cuja capital possui o mesmo nome, que engloba, entre outras, as cidades Sicasica e Pacages; 7 - intendência de Cochabamba, cuja capital possui o mesmo nome, que engloba, entre outras, as cidades de Santa Cruz de la Sierra e Valle Grande; 8 intendência de Charcas, cuja capital é La Plata, que engloba, entre outras, as cidades de Oruro e Tomina. Para termos noção do tamanho territorial do ViceReino, destacamos que apenas os territórios de três dessas intendências fazem parte da atual República Argentina.

Com o final da Revolução de Maio, a Junta viu a necessidade de aumentar a sua zona de influência para o resto da região do antigo vice-reino. Para tanto, enviou uma circular para as outras cidades e vilas, expondo os motivos de sua

\footnotetext{
${ }^{28}$ Gazeta de Buenos-Ayres número 03, 21 de junho de 1810, p.3.

${ }^{29}$ Intendencias eram regiões territoriais administrativas com o poder centralizado na figura do Intendente. Esse por sua vez era um oficial da coroa e tinha como principal missão fomentar a economia e resguardar o tesouro real na região.
} 
criação e convocando aquelas que quisessem aderir ao seu projeto de governo: deviam nomear deputados que fossem a Buenos Aires discutir o futuro do governo da região. Esta circular foi publicada no segundo número da Gazeta de Buenos-Ayres de onde podemos destacar o seguinte trecho da edição número dois:

"Este es el gobierno que se ha erigido provisionalmente hasta la reunion de los Diputados de todas las Provincias. El Pueblo de Buenos-Ayres no pretende usurpar los derechos de los demas del Vireynato, pretende si, sostenerlos contra los usurpadores. Conoce que la unión reciproca de todas las Provincias es el único medio de su conservación: conoce que para cimentar la confianza deben oírse los votos de todos, y establecer un gobierno que se derive de la voluntad general de los que han obedecer. La remoción del Excmo. Sr. Virey no admitia espera, y se consideró necesaria en obsequio de la salud pública. Era indispensable nombrar un depositario de la Autoridad Superior que obtubiese la confianza del Pueblo, para contener los males que nos amenazaban; y porque este debe ser á satisfaccion de todos los que le han de reconocer, el mismo Pueblo ha pedido que se provisional, y que se convoquen todos sus hermanos para el nombramiento de Diputados de las Ciudades y villas, de que reunidos en esta Capital establezcan el gobierno que haya de merecer toda su confianza y respeto, y que sea la base de su prosperidad. ${ }^{, 30}$

Neste trecho percebemos que Buenos Aires tinha como meta ser o centro desta nova região autônoma. Embora "El Pueblo de Buenos-Ayres no pretende usurpar los derechos de los demas del Vireynato”, a Junta pretendia que a Capital e o principal poder político e econômico deste novo modelo de governança fosse Buenos Aires.

Apesar da circular, nem todos os "pueblos" da região do Prata concordavam com a instalação da Junta Governativa. Podemos citar como opositores à formação do governo portenho as regiões dos "pueblos" de Montevideo, Córdoba e Salta. A Gazeta deu destaque às manobras feitas por essas cidades opositoras para impedir o crescimento da influência desta no território do antigo Vice-Reino do Prata como veremos a seguir.

O seguinte trecho escrito pelo Deputado da cidade de Mendonça mostra essa disputa entre aqueles que apoiavam o Conselho de Regência e os que eram a favor da Junta Provisória de Buenos Aires.

"Quando aplaudia este pueblo, con extraordinarios transportes de júbilo, la noticia que tubo de por el correo de Buenos Ayres de la instalacion de la Junta Provisional Gubernativa del Rio de la Plata, y se determinaba convocarse para el

\footnotetext{
${ }^{30}$ Gazeta de Buenos-Ayres número 02, 14 de junho de 1810, p. 6-7.
} 
nombramiento de Diputado, por ser el sentir uniforme deste vecindario; entonces llega um extraordinario de Cordoba em que ordena el Gobernador no se le preste obediência á la Junta por ser abusivamente instalada, y que por lo mismo no se reconecia por aquel Cabildo, ni por el de Montevideo, y Salta; ${ }^{, 31}$

Para enfrentar os opositores e consolidar o seu poder, a Junta organizou expedições militares ao interior para as regiões norte do antigo Vice-Reino e da intendência do Paraguai. A expedição que se dirigiu a região do Alto Peru (intendência de Charcas) logo se deparou com resistência em Córdoba, onde rapidamente as tropas portenhas derrotaram seus inimigos, derrubaram o Governador Intendente e colocaram no poder um novo líder (aliado de Buenos Aires) comprometido com os ideais da Junta, que se comprometeu a convocar eleições de deputados para serem enviados a capital, como podemos ver no seguinte trecho do periódico:

"Tengo la satisfaccion de anunciar V.E. la quietude, tranquilidade, y buen orden que reynan em esta Ciudad (...)

El pueblo todo admira uma conducta que ni aun los mas apasionados a la justa causa pudieron esperar, y ella ha vencido de tal modo la obstinacion aun de los mas alucinados, que vemos restituirse á sus casas todos los dias porcion de familias á quienes la malignidade de los mandatarios antiguos y las continuas exortaciones del Obispo em los templos, y confessionários habian profundamente impressionado.

Para acabar de consolidar esta union, y para cumplir debidamente com las ordenes que al efecto me ha significado el nuevo Gobernador Intendente, se há dispuesto que para el 19 imediato se haga uma pública, y solemne funcion á que concurra todo lo principal, y mas lucido deste vecindario, pues para aquel dia se miran em reunion los motivos de nombriamento de Diputado(...),32 (negrito meu)

O seguinte trecho é uma carta escrita ao periódico, que trata da derrota dos opositores da Junta de Buenos Aires em Córdoba. Também é uma confissão de um membro desta cidade sobre o temor de que ocorresse uma guerra civil de longa duração entre Córdoba e Buenos Aires.

"No satisfecho ese Pueblo victorioso com los timbres que ha adquirido dentro de su recinto, su genio emprendedor lo impele a dilatar sus proezas por los climas internos de nuestro continente. Es indudable, que una de ellas es destronizar al depotismo inverterado por la proteccion é impunidad.

Com sola la noticia de aproximarse á este vecindario el exército encargado de su exterminio, el pavor que le ahorro su execucion(...)

\footnotetext{
${ }^{31}$ Gazeta de Buenos-Ayres número 10, 09 de agosto de 1810, p. 8

${ }^{32}$ Gazeta de Buenos-Ayres número 12, 23 de agosto de 1810, p. 9-10.
} 
Su existencia era no solo um peligro para la mia, sino tambien un obstaculo para prestar, y declarar mi sumision á V.E. por los conductos ordinários. Sin libertad, y tan expuesto hubieran sido inútiles, y aun trágicos mis esfuerzos. Estos son los motivos, porque he demorado la contestacion a el oficio de esa Superioridad de diez de Julio ultimo. ${ }^{, 33}$ (negrito meu)

Nesta passagem podemos ter uma ideia das mudanças que estão ocorrendo no vocabulário politico da região durante essa nova forma de experimentação política. Analisemos melhor os termos destacados acima, temos a utilização do termo "Pueblo" em seu caráter político como já foi discutido anteriormente neste capítulo. A expressão "Pueblo victorioso", segundo o autor, se refere aos portenhos que querem levar seus ideais políticos, neste caso a autonomia política, para o resto da região do Prata.

Ao utilizar o termo "libertad" e a expressão "depotismo inverterado", o autor o faz em um caráter político dos termos. Aqui o "depotismo” está ligado aos opositores à Junta e apoiadores do Conselho de Regência enquanto os portenhos são libertadores da região, pois têm como objetivo livrá-los dos grilhões deste domínio e oferecer-lhes sua liberdade política.

Por fim temos a utilização do termo "vecindario" que aqui aparece no sentido de lugar onde vivem os "vecinos" conceito muito utilizado na América Ibérica no período colonial, mas que aos pouco irá cair em desuso por está intimamente ligado ao Antigo Regime na região, sendo substituído pelo conceito de "ciudadano" que será discutido mais adiante. "Vecino" era:

“(...) el habitante varón que vivía en la ciudad com capacidades civiles plenas, el que se asentaba en el campo a poblar en calidad de hacendado, de comerciante o de labrador. "34

A oposição à Junta não estava apenas longe da Capital. Do outro lado do Rio da Prata, a cidade de Montevidéu que jurou lealdade ao Conselho de Regência, e declarou sua autonomia de Buenos Aires se tornou um reduto dos interesses da península na região que tentou desmantelar o Governo Provisório.

\footnotetext{
${ }^{33}$ Gazeta de Buenos-Ayres número 13, 30 de agosto de 1810, p. 1-2.

${ }^{34}$ CANSANELlO, Oreste Carlos. Ciudadano. Argentina - Río de la Plata. In: SEBASTIÁN, Javier Fernández (Org.). Diccionario político y social del mundo iberoamericano. La era de las revoluciones, 1750-1850. Madrid: Fundación Carolina, Sociedad Estatal de Conmemoraciones Culturales, Centro de Estudios Políticos y Constitucionales, 2009, p. 199.
} 
Sofrido o golpe o presidente da Junta, Cornelio Saavedra escreveu uma Ordem do Dia, publicada na Gazeta onde fez uma crítica ao "pueblo subalterno" (lembrando que Montevidéu era subordinada a Buenos Aires durante o ViceReino) pelas hostilidades e insultos dirigidos aos portenhos durante o bloqueio realizado por navios espanhóis baseados do outro lado do rio e por sua declaração de separação entre as cidades.

"Quando en el curso de los sucesos humanos se ve precisado um pueblo á romper los vínculos que lo ligaban á otro, es um debe de justicia, que por respeto á las opiniones de los demas hombres, se manifesten los motivos que han conducido á esta separacion. La Capital de Buenos Ayres, inseparable de las medidas de moderacion que se ha propuesto, tento todo los medios legitimos de unirse estrechamente á Montevideo, esperó que uma franca comunicacion corriese el velo á las imposturas com que al principio se desfiguró su conducta, guardó uma constante adhesion á los princípios de fidelidad que habia jurado, hizo respetar los derechos de aquel pueblo y las relaciones de interés, que nos unian á el, y hoy dia que se halla reducida á la dura necesidad de romperlas, tiene la satisfaccion de anunciar em su anterior conducta un justificativo de la presente, y en la obligacion de sostener su dignidad y decoro, el principio legitimo de las providencias eficaces que ha resuelto oponer á los insultos y hostilidades de Montevideo.

Son ya desmasiado notorios los motivos, que produxeron la instalacion de la Junta em la Capital, y Montevideo no debió oponerse á la substancia del proyecto, despues que con menores fundamentos sostubo su Junta de Observacion que obtuvo aprobaciones de la Corte em el acto de disolverla. Las apologías que se escribieron en favor de aquella resolucion, justificaban la nuestra; y uma ciudad del rango de Buenos Ayres no debió esperar resistencia de um pueblo subalterno, que habia clamado tanto por la integridad de aquellos derechos, que en las circunstancias del dia autorizan á los pueblos para semejante conducta., 35

As disputas pelo apoio à Junta continuaram ao longo do ano e as próprias intendências começaram a se movimentar para defender os seus interesses políticos de apoio ou não a Buenos Aires. O seguinte parágrafo foi retirado de um ofício enviado pelo governador de Cochabamba para o governador de La Paz ameaçando-o pela força das armas a escutar as vozes do povo e a obedecer a Junta Provisória:

"En fuerza de estos justos convencimientos me resuelvo a pasar a V.S. el presente oficio, exhortándolo a que en desempeño de sus primeras, y mas imprescindibles obligaciones, escuse contra esos fidelísimos habitantes de todo

${ }^{35}$ Gazeta de Buenos-Ayres número 11, 19 de agosto de 1810, p. 1-2. 
motivo de opresión: escuche su libre voluntad en quanto a obedecer la referida Excma. Junta Superior de la Capital de Buenos Ayres, y execute lo que a unánime conformidad del pueblo determine, en los presentes asuntos, los quales muy distantes de ofender los sagrados derechos de la soberanía, se dirijen en todo su conato, y con todo su esfuerzo á sostenerlos ilesos contra los peligros susceptibles á las desgracias de nuestra madre España. Sí así no lo haga V.S., y si el término preciso para contestarme como espero, se pasa en silencio, será consiguiente presentarme en esa ciudad al frente de las inmensas tropas, que hé organizado para sujetar espiritus revolucionarios, y para restituir a los oprimidos pueblos la libertad de que carecen, y será también que V.S. sea responsable de todas la consecuencias, y principalmente de los dispendios de la real hacienda. ${ }^{\text {"36 }}$ (negrito meu)

No trecho destacado em negrito no fragmento acima, o termo "pueblo" possui um caráter politico: são os detentores da soberania. Podemos ver uma vinculação deste com a palavra "libertad" (em uma acepção política), o que mostra que, para aqueles que defendiam a Junta de Buenos Aires, os termos povo e liberdade andavam juntos. O primeiro necessitava de liberdade política para ser realmente livre.

\subsection{Recebimento da instalação da junta no Brasil e no Peru}

Até aqui vimos como as regiões do antigo Vice-Reino do Prata receberam a noticia da formação da Primeira Junta de Governo. Veremos agora como esta foi recebida por duas outras regiões do continente americano - Brasil e Lima, capital do Vice-Reino do Peru - o que foi publicado pela Gazeta de Buenos-Ayres e como ela tratou deste assunto.

O seguintes trechos apresentam a chegada de uma proclamação do Marquês de Casa Irujo, Ministro da Junta Central na Corte brasileira, que demonstrava a sua preocupação com a mudança da forma de governo na região do Prata e a tentativa deste de restituir as províncias ao controle do antigo Vice-Rei da Província do Prata Baltasar Hidalgo de Cisneros de la Torre.

"Ha llegado á esta ciudad una proclama impresa em el Rio Janeyro, y dirigida a los habitantes españoles de la América Meridional. Su autor, el Marqués de Casa Irujo, Ministro extraordinario de la Junta Central em la Córte de Brasil, se manifesta agitado por la instalacion de la Junta Provisional de gobierno de estas Provincias, y afectando grandes temores y recelos, la supone origen seguro de los mismos males em cuya precaucion ha estabelecido.(...) Su objetivo es restituir a Sr. D. Baltasar Hidalgo de Cisneros em el mando de estas

\footnotetext{
${ }^{36}$ Gazeta de Buenos-Ayres número 25, 22 de novembro de 1810, p. 3-4.
} 
Provincias. (...) No esta em nuestra mano complacer al Marqués en la primera parte de su demanda, ni creemos que los demas pueblos reciban gustosos el funesto presente de la guerra civil y general desolacion á que se les convida. ${ }^{\text {,37 }}$

O seguinte fragmento faz parte da resposta dada pelo editor à proclamação do Marques de Casa Irujo:

"Es um cargo terrible contra el Marqués, haber soplado el fuego de la discordia y la guerra civil entre unos Pueblos, que reconecen los derechos de su legitimo Monarca el Sr. D. Fernando VII.(...)” (p.1)

“(...) pero conecemos muy bien, que nada pudo ocurrir mas contrario á sus ideas, que el estabelecimento de este nuevo Gobierno. Los Pueblos piensam libremente sobre si mismos, y sus derechos se consultan sin los prestigios en que el abuso del poder los envolvia. "38

Em ambas Moreno afirma que a única maneira de dissolver a Junta seria através da guerra e que a população estava disposta a pegar em armas para defender a sua soberania. Novamente a noção de autonomia da época, de governar em nome de Fernando VII e não de seccionar do Império Espanhol, aparece nas palavras proferidas pelo representante da Junta.

O seguinte artigo trata da tentativa do governo do Peru de afastar da região da intendência de Charcas, na região do antigo Vice-Reino do Prata estas, ideias de autonomia provenientes da Junta de Buenos Aires.

"Hacen muchos dias, que la Junta sufocaba em el silencio el justo dolor del vexamen inferido por el Presidente de Charcas á los Patricios de aquella guarnicion: el Pueblo tenia derecho a se instruido puntualmente el la afrenta de sus conciudadanos; (...)

El mas seguro recurso de los tiranos es la division de los pueblos, pues equilibrada entonces su fuerza, quedan al fin despedazados y sujetos: este el medio que los Gobernadores del Perú se han propuesto para sostenerse en sus usurpaciones, y de aqui nacen estas ridiculas imposturas, com que pretenden hacer odiosos á los peruanos el nombre de Buenos Ayres.(...)

No, generosos Peruanos! Vuestra iustracion está muy acreditada, para que os dexeis alucinar de pretextos tan ridiculos: uníos estrechamente a vuestros Hermanos de Buenos Ayres que no quieren dominarlos sino romper vuetras cadenas. " 39

Neste mesmo segmento surgem três termos que representam a sociedade ou parte dela, em sua de forma a distinguir aqueles que possuem poderes políticos

\footnotetext{
${ }^{37}$ Gazeta de Buenos-Ayres número 07, 19 de julho de 1810, p. 1-2.

${ }^{38}$ Gazeta de Buenos-Ayres número 08, 26 de julho de 1810, p. 4.

${ }^{39}$ Gazeta de Buenos-Ayres número 14, 06 de setembro de 1810, p. 1-3.
} 
naquela sociedade ou não. O vocábulo "Pueblo" tem como significado aqueles que possuem poder político na comunidade. Neste trecho pode-se notar uma vinculação do termo com a palavra “derecho” reforçando esse caráter político. "Conciudadanos" seriam os membros da comunidade de Charcas que não faziam parte "del Pueblo", ou seja, os moradores da comunidade que não possuiam poder político naquela localidade. Por fim, "Los pueblos” aqui são os depositários de sua própria soberania membros das diversas comunidades presentes no continente americano.

\subsection{Discussões sobre a instalação da junta}

A pressão por parte dos opositores pela ilegalidade da formação da Junta Governativa, fez com que esta respondesse através de um manifesto em sua defesa ressaltando que o governo portenho governava em nome de Fernando VII, buscando autonomia da Junta Central espanhola a qual não consideravam como seu soberano, como pode ser visto no trecho a seguir, no manifesto publicado na edição número dezenove da Gazeta:

"La época de nuestra instalación (Junta de Buenos Aires) era precisamente la de la disolución de la Junta Central (...) El digno objeto de nuestro culto es el de la constitución nacional. Juramos por nuestro Rey legitimo al Sr. D. Fernando VII; y protestamos dependencia del poder soberano, que sea legítimamente constituido; llenando con esta sagrada protesta el primero y mas esencial deber de nuestra acreditada lealtad. No presentamos a los pueblos de nuestra dependencia un reconocimiento nominal, ni un titulo de vana ostentación, con que autorizemos la perfidia. Un sistema sostenido, ligado escrupulosamente por las pautas formadas para conservar la dependencia de estos territorios á la obediencia de nuestros soberanos, es el mas seguro intérprete de nuestros fieles sentimientos.

Ciudadanos: Vosotros sois testigos de nuestra conducta, y sabeis de nuestros rivales no son capaces de en ella un solo ápice, que nos desmienta. Señálense todos los caracteres de la independencia é insurrección: ellos son irreconciliables con nuestros principios; " 40

Este manifesto expõe a concepção de autonomia que os membros da Junta possuíam. Se analisarmos o termo em si, o vocábulo "autonomía” aparece pela primeira vez no Dicionário da Real Academia Española em 1869 na seguinte acepção: "La condicion en la cual un estado ó un individuo, con entera libertad é independencia, aquello que contituye su manera de ser esencial, característica y

\footnotetext{
${ }^{40}$ Gazeta de Buenos-Ayres número 19, 11 de outubro de 1810, p. 3-6.
} 
propia. "41 Esta acepção é muito próxima ao sentido do termo atualmente, mas totalmente distinta daquela proposta pelos portenhos na segunda década do século XIX. Para os membros da Junta tornar-se independente neste momento era o mesmo que insurgisse contra os princípios desta, que pregava que seu principio de autonomia era governar em nome de Fernando VII até que esse pudesse recuperar o seu trono.

Este texto vem ao encontro de um artigo da própria Gazeta, publicada no número anterior, em que Moreno discute o que é soberania e onde ela reside. A resposta do autor é que a soberania reside "en el pueblo" e esta não pode ser transmitida sem o consentimento deste. Criticando desta maneira a formação do Conselho de Regência que havia ocorrido sem a consulta e aprovação de "los pueblos", o que caracterizava o impedimento de sua Soberania sobre a nação espanhola, pois com a queda de Fernando VII esta, no modo de ver do autor, voltou aos povos do Império.

"Pero aun quando se quiera suponer su legitimidad, ¿podrá acaso deducirse que también podía transmitir la Soberanía? La Soberanía reside únicamente en el pueblo, y quando el la deposita en un individuo, este individuo no adquiere el derecho de desposeerse de ella, y de transferirla sin consentimiento del pueblo, y asi quando Carlos $V$ y Felipe $V$ abdicaron en favor de sus hijos, no lo hicieron después de haber consultado á la nación. Y se estos Reyes para transferirse la Soberanía, a sus hijos que habian ya sido reconocidos y jurados herederos de ella, tuvieron que consultar a la nación ¿como puede decir el Consejo de Regencia que la Junta Suprema podía crear un Soberano sin la participación de la nación, y transferir la Soberanía a cinco individuos, que no tenían derecho alguno a ella? ${ }^{, 42}$

Para terminar a análise proposta no início desse capítulo, apresentamos o fragmento a seguir, retirado do editorial do periódico de número vinte e sete. Nele, o autor discorre sobre a necessidade da criação de uma constituição que pudesse proteger "los pueblos" do poder arbitrário e do despotismo. Para tanto ele vê necessária a realização de uma assembleia com todos os representantes dos povos livres de Espanha, incluindo os da América. No caso da soltura do monarca

\footnotetext{
${ }^{41}$ Diccionario de la Real Academia Española. Diccionario de la lengua castellana por la Real Academia Española. Undécima edición. Madrid: Imprenta de Don Manuel Rivadeneyra, 1869. p 89.

${ }^{42}$ Gazeta de Buenos-Ayres número 18, 04 de outubro de 1810, p. 12.
} 
e de sua recondução ao trono, também este deveria respeitar a constituição criada pelos "pueblos":

"Nuestras provincias carecen de constitución; y nuestra vasallaje no recibe ofensa alguna, porque el congreso trate de elevar los pueblos, que representa á aquel estado político, que el Rey no podría negarles, si estuviese presente. Pero ¿podrá una parte de la América por medio de sus legítimos representantes establecer el sistema legal, de que carece, y que necesita con tanta urgencia; ó deberá esperar una nueva asamblea, en que toda la América se dé leyes á sí misma, ó convenga en aquella división de territorio, que la naturaleza misma ha preparado? Si consultamos los principios de la forma monárquica, que nos rige, parece preferible una asamblea general, que reuniendo la representación de todos los pueblos libres de la Monarquía, conserven el carácter de unidad, que por el cautiverio de lo Monarca se presenta disuelto. El gobierno supremo, que estableciese aquel congreso, subrogaría la persona del príncipe, en todo los estados, que había regido antes de su cautiverio, y si algún día lograba la libertad, porque suspiramos, una sencilla transmisión le restituiría el trono de sus mayores, con las variaciones, y reformas que los pueblos hubiesen establecido, para precaver los funestos resultados de un poder arbitrario." $" 43$

Enquanto Moreno escrevia este texto, em Cádiz as Cortes já buscavam maneiras de criar uma Constituição para o Império Espanhol, que ficou pronta em 1812.

Em seu primeiro decreto, de 24 de setembro de 1810, as Cortes de Cádiz proclamaram-se depositárias do poder da nação, ou seja, afirmaram sua soberania, como tinha acontecido em Buenos Aires, no outro lado do Atlântico, em maio do mesmo ano. Esta acepção de soberania aparece no terceiro artigo da Constituição de 1812 que diz: "La soberanía reside esencialmente en la Nacion, y por lo mismo pertenece á esta exclusivamente el derecho de establecer sus leyes fundamentales ${ } .{ }^{44} \mathrm{O}$ mesmo decreto também estabelece que todos os cidadãos que formavam a nação eram iguais em direitos e estavam sujeitos às mesmas leis.

\footnotetext{
${ }^{43}$ Gazeta de Buenos-Ayres número 27, 06 de dezembro de 1810, p. 1.

${ }^{44}$ Constitucion Política de la Monarquía Española. Cádiz: Imprenta Real, 1812. p. 7.
} 


\section{A Gazeta de Buenos-Ayres no ano de 1811: Principais discussões}

Se a Gazeta teve em 1810, em sua maior parte Mariano Moreno como editor, a partir de 1811 ela terá quatro editores: Deán Funes, de dezembro de 1810 até março de 1811; Pedro José Agrelo, desde 18 de março até 5 de outubro de 1811; Vicente Pazos Silva e Bernardo Monteagudo, até 8 de outubro de 1812.

Gregorio Funes, também conhecido como o Deán Funes, foi um político e eclesiástico argentino, reitor da Universidade de Córdoba. Defensor da Revolução de Maio foi nomeado deputado por Córdoba, tornando-se um membro e diretor político da Junta Grande.

Antes de continuarmos, cabe lembrar o que foi a Junta Grande. Em dezembro de 1810, quase todos os deputados do interior convocados pela primeira proclamação da Junta após a Revolução de Maio tinham chegado a Buenos Aires e solicitado sua incorporação ao governo.

Em 18 de dezembro foi realizada uma reunião entre os sete membros da Primeira Junta que estavam em Buenos Aires e os nove deputados das províncias que tinham vindo do interior para votar a solicitação dos deputados. Cornélio Saavedra, Miguel de Azcuénaga, Manuel Alberti, Domingo Matheu, Juan Larrea, Manuel Ignacio Molina (deputado por Mendonza), Juan Francisco Tarragona (deputado por Santa Fe), José Símon Garcia de Cossio (deputado por Corrientes), Francisco de Gurruchaga (deputado por Salta), Manuel Felipe Molina (deputado por Tucumán), Gregório Funes (deputado por Córdoba), José Julian Perez (deputado por Tarija), José Antonio Olmos de Aguilera (deputado por Catamarca) e Juan Ignacio Gorriti (deputado por Jujuy) votaram todos a favor da incorporação dos deputados, enquanto Passo votou contra. Mariano Moreno pronunciou-se contra a medida proposta, mas acabou votando a favor.

No dia seguinte, realizou-se o juramento constituindo a Junta Grande. Com várias mudanças em sua composição, ela governou até 22 de setembro de 1811 
quando foi substituída devido ao golpe institucional liderado pelo Cabildo de Buenos Aires. Isto levou ao governo o Primeiro Triunvirato, que voltaria a ter tendências centralizadoras como as da Primeira Junta.

Após Funes, o editor foi Pedro José Agrelo advogado e político argentino. Ao contrário dos demais editores da Gazeta, não participou diretamente da Revolução de Maio. Por outro lado, se destacou por ser presidente da Assembleia Constituinte de 1813 e autor do projeto de Constituição Argentina desse ano. Após o afastamento de Agrelo, o sacerdote Vicente Pazos foi indicado para assumir seu posto. Este, além de religioso, era um político, escritor e jornalista.

A partir do dia 5 de novembro de 1811 a Gazeta teve a sua numeração reiniciada. Além disso, o periódico passou a ser publicado dois dias por semana: às terças-feiras e sextas-feiras. Em 20 de dezembro a Junta decretou que a editoria do periódico seria dividida entre Pazos e Bernado Monteagudo como podemos ver a seguir, na publicação do dia 24 do mesmo mês:

"Como el honor del Editor se interesa en los papeles que baxo su direccion se imprimen en la gazeta de esta capital, parece necesario informar al público de que el superior gobierno ha determinado asociar para este trabajo al Dr. D. Bernardo de Monteagudo quien deberá formar una de las gazetas que semanalmente se dan á luz; y aunque si sus nombres se confundiesen, ganaria sin duda mucho el antiguo Editor con las luces y acreditados talentos del Dr. Monteagudo, sin embrago, parece justo que ninguno sea responsable, sino de que lo escribe, por cuya razon al paso que se inserta el decreto dado por el gobierno en este particular, se previene que las gaszetas $N^{o} 12$ y 14 son del nuevo Editor, y que las que en adelante trabajarse el antiguo llevara ahí la iniciales de su nombre.

\section{DECRETO}

Buenos Ayres 20 de diciembre de 1811.

Sin embrago que la redaccion de la gazeta no es una comision ministerial; como no lo es el periodico sino en los artículos de oficios; en justa satisfacion á los sentimientos del suplicante se declara, que el encargo conferido al Dr. Monteagudo no ha tenido otro objeto que facilitar el despacho, consultando en la alternativa semanal de ambos redactores. ${ }^{, 45}$

José Bernardo de Monteagudo foi advogado, político, jornalista, militar e revolucionário. Pertencia a ala mais radical da Revolução e era muito próximo de Juan José Castelli vocal da Primeira Junta.

\footnotetext{
${ }^{45}$ Gazeta de Buenos-Ayres número 15, 24 de dezembro de 1811, p. 1.
} 
Da mesma forma que no capítulo anterior, dividiremos os trechos selecionados em três temas transversais às discussões do vocabulário político do ano de 1811: as discussões sobre a governança das províncias, seja sob o governo da Junta Grande, seja durante o Primeiro Triunvirato; a guerra civil entre Buenos Aires e Montevidéu; e, por último, as discussões levantadas pelos editores acerca da liberdade.

\subsection{Discussões acerca da governança das Províncias.}

Uma das principais medidas da Junta Grande foi a organização do território em governos de províncias na forma de Juntas Locais. Na edição 36 da Gazeta publicou-se uma ordem do dia sobre essa nova forma de organização política. Primeiramente os membros da Junta explicavam o porquê de organizar o governo daquela maneira:

"Los mismos motivos que obligaron á sostituir una autoridad colectiva a la individual de los vireyes, debieron tanmbien introducir una nueva forma em los gobiernos subalternos. El justo temor de no arriesgar unos primeiros pasos, que debian decidir de nuestra suerte en la premura de un tiempo en que esta Junta no tenia confianza de los pueblos, la puso em la necesidad de no alterar o sistema antiguo, depositando los gobiernos en mano de uma fidelidad á prueba de peligros. Por los demas, la Junta siempre ha estado persuadida, que el mejor fruto de esta revolucion debia consistir em hacer gustar á los pueblos las ventajas de un gobierno popular. ${ }^{, 46}$

Podemos ver a diferença de propostas entre a Junta Provisória e a Junta Grande, se a primeira tinha intenções de concentrar o poder político na cidade de Buenos Aires, a segunda colocava o poder em órgãos locais eleitos pelo "Pueblo" da localidade. Continuando, o texto explicita como deveriam ser aqueles que governariam as províncias:

"Esta clase de gobierno ofrecerá magistrados poderosos, pero esclavos de las leyes, ciudadanos libres, pero que saben que no hay libertad para el que no ama las leyes, virtudes civiles, virtudes politicas, amor de la de la glória, amor de la patria, disciplina austera, y en fin hombres destinados á sacrificarse por el bien del estado. Para que esta grande obra traga su perfeccion cree tambien la Junta,

\footnotetext{
${ }^{46}$ Gazeta de Buenos-Ayres número 36, 14 de fevereiro de 1811, p. 1.
} 
que será de mucha conducencia el que los individuos de estas Juntas gubernativas sean elegidos por los pueblos. ${ }^{, 47}$ (negrito meu)

O governante dessas localidades era o exemplo de membro do "Pueblo": o cidadão que colocava a pátria acima da própria vida. Percebamos a mudança de acepção do termo "patria", se anteriormente vimos que este tinha sentido territorial, aqui aparece com uma acepção política, ligada ao Estado.

Se, por um lado, mudou a forma de pensar como deveria organizar-se o governo, por outro manteve-se a posição da Junta Grande em relação ao Conselho Regência. Como critica a esta e também às cortes convocadas por este órgão, vejamos uma publicação da Gazeta:

"Las cortes españolas ni contenien hoy, ni han contenido jamas la voluntad general, porque su estabelecimiento no lo deben á una primera asociacion en que los españoles se conviniesen libremente á refundir las suyas en estas asambleas: antes por el contrario,los actos fundamentales de que deriva su origen la monarquia española han sido de fuerza, de desolacion y de conquista; por consiguiente, si algun derecho han adquirido despues los pueblos para enviar sus comisarios á una junta general, ha sido para hacer suplicas y peticiones al Rey á nombre de sus provincias, y por virtud de gracia y favor del príncipe, que como absoluto y verdaderamente despótico, hacía las variaciones y limitaciones que le convenia, para que su autoridad no decayese; basta saber la fórmula com que ellos hacían sus peticiones, y el decreto con que el Rey respondia á cada una, para no dudar de esta verdad. ¿Son estos acaso los medios de llegar á la associacion soberana, que reune las voluntades particulares de todos, y constituye aquel cuerpo moral, cuya existencia esta em la coleccion de las partes que lo componen? Podran decirnos, que sus córtes no han sido convocadas em estas circunstancias por el Rey; que los diputados no son tan solamente de las ciudades privilegiadas sino de todos los pueblos, que han concurrido com sus respectivos sufragios, y no se hallan por lo mismo em el caso de aquella censura.

No hallamos que por eso mejoren su causa, porque los indivíduos de la Regencia se hallaban desnudos de la investidura necesaria para incitar a la eleccion y reunion de los diputados: esta es otra condicion tan importante para legitimidad del congreso general, como proprio de los pueblos el verificarla. "48

Para o editor (Funes), as cortes não possuíam legitimidade por dois motivos: 1 - o privilégio das regiões da península em detrimento das colônias no número e no modo de escolha de seus representantes e 2 - se o Conselho de Regência não era depositário, como poderiam ser legítimas as convocações feitas por esta.

\footnotetext{
47 Idem.

${ }^{48}$ Gazeta de Buenos-Ayres número 39, 07 de março de 1811, p. 4-5.
} 
As expedições militares iniciadas durante o governo da Junta Provisória, para conseguir apoio de todas as províncias do antigo Vice-Reino, começaram a sofrer reveses. Em 1811, no Paraguai, a expedição liderada por Belgrano foi vencida em Paraguarí (19 de janeiro). Após a nova derrota das forças portenhas na batalha de Tacuarí, em maio, uma revolução aconteceu em Assunção, o que obrigou o governador a declarar a autonomia da província do Paraguai em relação a Buenos Aires. A expedição ao Alto Peru (região norte) que triunfou em 1810 foi derrotada em Huaqui (20 de junho) pelas tropas realistas. Com o medo da perda destes territórios, o presidente da Junta Saavedra seguiu para o norte para tomar o comando das tropas. Essa perda de prestígio da Junta levou o Cabildo, em 23 de setembro de 1811, a decidir pela formação de um Triunvirato que concentraria o poder executivo, composto por Feliciano Antonio Chiclana, Manuel Sarraeta e Juan José Paso. A Junta Grande passou a atuar como Junta Conservadora tendo papel legislador.

Na edição de 17 de outubro, o periódico publica um edital sobre a autoridade de um governo nacional e o papel do povo nesta autoridade.

"Mientras los hombres ilustrados decidan de la teoria de estas proporciones, debemos reflexionar sobre el verdadero influxo, que experimentan los pueblos, inmediatamente que depositan su confianza en la autoridad, que constituyen: baxo de un gobierno nacional vigoroso, la fuerza natural, y recursos del pais, dirigidos à un interés comum eluden todas las combinaciones de la emulacion. Un gobierno enérgico, que evita los motivos à semejantes combinaciones, es el mas noble objeto que se ofrece à la contemplacion de los hombres. Para conocer la bondad de éste, es preciso considerar el pueblo que lo obedece; entonces se puede juzgar de su excelencia en las costumbres, y en el bien público. Es verdad, que cada uno quiere resolver à su modo este bien: los súbditos ensalzan la tranquilidad pública; los ciudadanos la libertad de los particulares; el uno prefiere la seguridad de las posesiones; el otro la de las personas; unos quieren que el gobierno mejor sea el mas severo; otros el mas blando; unos pretenden que se castiguen los crimenes, y otros que se prevengan; otros el ser ignorados; unos estan contentos, quando el dinero circula; otros quando el pueblo tiene que comer, y como estas son quantidades morales, no tienen medida precisa. (...)

El verdadero resorte de la autoridad debe residir en la opinion, y en el corazon de los gobernados. El gefe que nos es amado, nunca podra corregir las costumbres, que deben mantener el gobierno; para conseguir esta confianza, es necesario avivar el espíritu público por la liberalidad, y conducta benéfica, que se conozca por el pueblo. ${ }^{, 49}$

\footnotetext{
${ }^{49}$ Gazeta de Buenos-Ayres número 71, 17 de outubro de 1811, p. 1-3.
} 
Em 22 de outubro de 1811, a Junta Conservadora decretou “el Reglamento Orgánico" que estabelecia os poderes do executivo, legislativo e judiciário. O regulamento compreendia três seções. A primeira seção atribuía à Junta Conservadora a autoridade para declarar guerra, paz, trégua, tratados de comércio, criar novos impostos, empregos ou tribunais, de nomear os membros do Executivo em caso de morte ou renúncia. Na segunda seção foram definidos os atributos dados ao Triunvirato: a defesa do Estado, a organização do exército, o cumprimento das leis, a segurança pessoal dos cidadãos. Finalmente, a terceira seção era dedicada à organização do judiciário ${ }^{50}$.

Ao receber o regulamento, o Triunvirato levou-o ao Cabildo argumentando que a Junta reservava a si muitas atribuições. Ao tomar conhecimento a Junta contra argumentou que o Cabildo, como órgão municipal, não tinha poder para julgar um regulamento feito pelos representantes das províncias. Essa manobra, utilizada pelo Triunvirato, tinha intenção de dissolver a Junta e tornar nulo o regulamento. Para substituir "el Reglamento Orgánico" foi redigido, em 22 de novembro, o "Estatúto Provisional", jurado em 01 de dezembro.

A seguir vemos um trecho da Gazeta sobre o acontecido.

"La alegria, el gozo que derraman los corazones, un suceso notable que á todos interesa, un favor extraordinario del cielo, un estatuto justo que contribuye á la fortuna y seguridad de todos, han sido la fuente y principio de todas la celebridades públicas. A los diez y ocho meses de haber resuelto Buenos Ayres ser libre, depues de tantos peligros, y contrastes causados ya por la varia fortuna de las armas, ya por los errores de su administracion, parece que empieza á marchar con paso firme por el sendero de su libertad. De nada servirian las buenas intenciones de los magistrados, sino sujetasen sua conducta á una regla que prescribiendo la forma del gobierno, afiance la libertad, seguridad, y propiedad de los ciudadanos: estos serían siempre vexados por la arbitrariedad, oprímidos por el despotismo.(...) El pueblo ha visto realizadas las esperanzas que concibio al reformar su gonierno en los dias de setiembre, quando agitado de funestos presentimientos, depositó en pocas manos sus interéses mas sagrados, e la concervacion de su libertad.

Desde que la fé humana y las promesas de los hombres perdieron esa firmeza que debia ser su inviolable caracter; desde que se desearon auntenticos testimonios de la verdad, se han exigido los juramentos públicos, para perpetuar la beneficencia contra los ataques de la ingratitud, ó para dar un carácter sagrado á las obligaciones de los hombres. Por este principio determinó el gobierno jurar públicamente el Estatúto Provisional formado en 22 de noviembre, para que

\footnotetext{
${ }^{50}$ Para ler todo o regulamento ver: CAILLET-BOIS, Ricardo R. Estatutos, reglamentos y constituciones argentinas 1811-1898. Buenos Aires: Universidad de Buenos Aires, 1956. 244 p.
} 
testigos multiplicados sean los monumentos firmes que conserven, y autorizen la responsabilidad á que se obligaron." 51

No trecho acima vemos uma crítica direcionada à Junta Grande que não conseguiu resguardar os interesses do "pueblo". E este, através do Cabildo, teria decidido que seria melhor colocar nas mãos do Triunvirato os seus interesses mais sagrados: a liberdade política, a segurança, e a propriedade.

A seguir, temos o juramento feito pelos membros do governo, no qual temos a primeira menção ao termo "Provincias Unidas del Rio de la Plata":

“'JURA EL SUPERIOR GOBIERNO PROVISIONAL DE LAS PROVINCIAS UNIDAS DEL RIO DE LA PLATA Á NOMBRE DEL Sr. D. FERNANDO VII. Á ESTA CAPITAL, Y DEMAS PUEBLOS UNIDOS, POR DIOS NUESTRO SEÑOR Y SOBRE ESTES SANTOS EVANGELIOS, OBSERVAR Y HACER CUMPLIR INVIOLABLEMENTE EL ESTATUTO Y DECRETOS QUE LE INTEGRAN, Y ACABA DE LEERSE?

SI JURA.

SI ASI LO HACEIS EN BENDICION Y PRO OS SEA, Y SINO EN MALDICION ETERNA." ${ }^{52}$

O Primeiro Triunvirato, resguardando-se contra qualquer poder que pudesse supostamente impedi-lo, decidiu mudar a estrutura do Regimento de Patrícios, que possuíam maiores privilégios por ser corpo de milícia, transformando-o em regimento de linha. Isto significava que os soldados seriam forçados a servir onde fossem destinados, sem limite de tempo, e em troca de um soldo acordado pelo governo.

Como primeiro passo dessas mudanças, o governo nomeou Manuel Belgrano como comandante do Corpo, colocando-o no lugar de Saavedra, sem consultar os soldados como anteriormente, na formação da milícia portenha. Outra mudança foi a ordem dada aos soldados para que removessem seu rabo de cavalo ou trança, em espanhol "trenza", que dá nome a revolta - Motín de las Trenzas -, símbolo da aristocracia dos Patrícios.

Na noite de 6 de dezembro de 1811, os oficiais se retiraram do quartel sede do Corpo dos Patrícios a pedido dos sargentos e cabos que tomaram o forte. $\mathrm{Na}$ manhã seguinte os soldados se encontravam sublevados. O Triunvirato tentou

\footnotetext{
${ }^{51}$ Gazeta de Buenos-Ayres número 09, 03 de dezembro de 1811, p. 1.

${ }^{52}$ Ibidem, p. 2.
} 
negociar com os amotinados, mas após as mediações infrutíferas de Juan José

Castelli e do bispo Benito Lue, o governo ordenou que o motim fosse suprimido.

A Gazeta de Buenos-Ayres apresentou em sua edição de número 14, um edital sobre os acontecimentos do dia 7 de dezembro.

"Instalada en la capital de los pueblos libres la primera Junta de gobierno, empezó nuestra revolucion á hacer tan rapidos progresos, que el que se detenia á observar su estado á los 6 meses, padecia la agradable e involuntaria ilusion de dudar, que aquella fuese la obra de sus coetáneos. Reducida la capital al estrecho circulo de si misma, emprende sin embargo dos expediciones al occidente y al norte sin mas objeto que llevar por todas partes el estandarte de la LIBERTAD. Sus armas triunfan de la tiranía, los pueblos proclaman su adhesion y el eco del patriotismo resuena por todas partes. Que energía en el sistema, que acierto en las deliberaciones, que concepto entre nuestros mismos enemigos que empezaban á tributarnos el homenage del temor. Pero ya se acercaba el tiempo en que las pasiones hablasen su lenguage natural, y se descubriesen los hypócritas cooperadores de esta grande obra. D. Cornelio Saavedra á quien por condescendencia a las circunstancias se le nombró presidente del gobierno, no pudo ver con indiferencia la gazeta del 6 de diciembre, que desde luego hacía un contraste á sus proyectos de ambicion; y emprende para llevarlos adelante, la incorporacion de los diputados á la Junta Gubernativa. El no dudaba que entre éstos encontraria facciosos capaces de prostituir su mision, y no se egaño en su cálculo.

Desde luego era de esperar que todo paso que diesen los diputados fuera del objeto de su convocacion sería tan peligroso como ilegal: ningun pueblo les delego mas poderes, que los de legislar y fixar la constitucion del estado; hasta el acto de la apertura del congreso no podia tener exercicio su delegacion, ni darles derecho á tomar parte en el sistéma provisional.(...)

No era facil subsieste la coacordia entre los nuevos gobernantes y los antiguos; y era muy natural que el en que los últimos habia descubierto un contraste a su ambicion, aspirasse á buscar en los primeros el apoyo de sus miras. Inmediatamente se sucito una rivalidad entre unos y otros, se formó una faccion, el mas ambicioso se hizo xefe de partido, y el mas dispuesto á la cabala, se encargo de susternelo.(...)

Nada digo que no esté probado por los hechos: los mismos pueblos que lloraban poco há la corrupcion del gobierno antiguo, vén hoy con asombro la imparcialidad y el espíritu de vida que anima las deliberaciones del actual: habrian tenido sen duda el dolor de ver prostituidos a algunos de sus delegados, mas tambien han recebido una saludable leccion para proceder con mas escrupulo á confiar el depósito sagrado de su representacion, y no aventurar su suerte seducidos de un zeloso hypocrita, de un sofista razonador, ó de un simulado patriota. La introducion de esta clase de hombres al gobierno nos ha causado todos aquellos males, y hemos estado expuestos á verlos reproducidos el 7 del presente. Este era el conato de los parricidas de la patria, esta su intencion: ellos hubieron querido destruir á los hobres de bien, y cobrar usura lo que habian perdido sus pasiones: ellos quiseron á costa de lo sangre del incauto soldado, subvertir el órden y triunfar de los que aman la justicia pero se engañaron, y 
ahora conocerá el mundo á los que son el oprobio de nuestra raza, y la causa de nuetros pasos retrogrados, y de nuestras anteriores desgraias. "53

O Triunvirato utilizou-se deste acontecimento para expulsar da capital os deputados vindos do interior das províncias, aumentando assim o seu poder em Buenos Aires. O periódico publicou um oficio do governo aos deputados das províncias unidas sobre uma possível conjuração por parte de alguns deputados contra a pátria.

\section{“Oficio Circular del Superior Gobierno á los Diputados de los pueblos}

El desgradable acontecimiento del dia 7 del corriente puso al gobierno en la necesidad de investigar por los medios legales los autores de una horrible conspiracion, que se tramaba contra su existencia por algunos de aquellos hombres malvados, á quienes la pérdida de su patria es un suceso indiferente, si conseguen llenar sus miras ambiciosas,ó satisfacer el espíritu de partido que les domina.

De las diligencias praticadas al efecto resulta plenamente justificado, que no era otro el objeto de su atrevida empresa, que restablecer á vmd. y á los demas diputados de las provincias en el gobierno, con el fin tal vez de cobrar con usuras el premio de este beneficio, prometiendose un influxo arbitrario sobre el destino de los pueblos. Las consequencias que necesariamente habrian seguido de la execucion de este plan contra los verdaderos interéses del estado, y lças dificultades de curar esta nueva herida en el corazon de la patria, no pueden esconderse á la ilustracion de vmd. Todo hubiera perecido, y el despotismo triunfado se gozaria al fin en la sangre de tantos compatriotas derramada en defensa de la libertad de sus hijos, y de la felicidad del suelo que nacieron.

$Y$ sí el gobierno hace a vmd. la justicia de creer que no habrá tenido parte en semejante atentado, no por eso dexa de conocer que siendo la exaltacion de los diputados la causa motiva de la conjuracion, serán inutiles quantas medidas se adopten para sofocar el gérmen de las revoluciones, inconveniente el mayor que pude oponerse á los progresos del sístema, sino se aleja el objeto en que se apoyan sus miras los facciosos para ganar prosélitos á la sombra de un protesto tan aparente.

Sobre este principio y en el concepto de que no pudiendo celebrase el congreso hasta que las provincias unidas hayan recobrado su libertad con el auxilio de nuestras armas, es no solo inutil, sino muy gravosa a los pueblos la existencia de sus diputados en esta capital, especialmente en un tiempo en que tienen que apurar todos sus recursos para atender á las grandes urgencias del estado, por esto ha creido el gobierno conveniente en acuerdo de esta fecha prevenir á $v d$. Se retire á su provincia disposiendo su salida dentro de 24 horas. "54

\footnotetext{
${ }^{53}$ Gazeta de Buenos-Ayres número 14, 20 de dezembro de 1811, p. 1-2.

${ }^{54}$ Gazeta de Buenos-Ayres número 13, 17 de dezembro de 1811, p. 5-6.
} 


\subsection{Guerra contra Montevidéu}

Para suprimir o movimento autonomista portenho, o Conselho de Regência tornou Vice-Rei do Rio de la Plata o antigo governador de Montevidéu, Francisco Javier de Elío. Este chegou às províncias em 2 de janeiro de 1811 e, evitando dirigir-se a Buenos Aires estabeleceu-se em Montevidéu, onde escreveu um oficio ao governo de Buenos Aires exigindo o reconhecimento de seu posto.

Vejamos como a chegada foi recebida nas páginas da Gazeta. Apresenta uma carta enviada ao periódico por um membro del Pueblo que assina o nome El Labrador, sobre a nomeação de D. Francisco Xavier Elio a Vice-rei do Prata pelo Conselho de Regência. Esta começa com um elogio ao trabalho da Junta:

“'Quán distinta fuera nuestra situacion política, y quanto mas avanzados nuestros pasos hácia nuestra libertad, si em todos los hombres de nuestro suelo fuera igual el talento é ilustracion á sus buenos sentimentos, y al amor de la patria que los inflama!" 55 (negrito meu)

Em seguida, o autor da carta faz referência à nomeação D. Francisco Xavier Elio e pede a aos Editores da Gazeta que se manifestem sobre o ocorrido:

"Aunque en mis cortos alcanzes me parece, que no debemos detenernos mas en manifestar los principios, que justifican nuestra causa, y la instalación de nuestro nuevo gobierno por que ninguna nación duda de ellos, y solo á golpes de convencerse el que afecta desconcerlos(...)

Es muy conveniente pues, formar la opinion pública en todas partes sobre este particular. El proporciona un campo muy extenso al discurso. Haga vmd. este servicio mas por la patria, y que se conserve este nuevo monumento para la historia de la América en la conducta de España; ${ }^{, 56}$ (negrito meu)

Analisemos os conceitos destacados nos trechos acima. O termo "libertad" possui caráter político: o povo do antigo Vice-reino do Prata tinha conseguido a sua autonomia da coroa espanhola. Liberdade esta que, segundo o autor da carta, seguia avançando.

O termo "pátria", em suas duas ocorrências, também possuem um significado político. Podemos ver que atrelados a este conceito estão os termos “amor" e "servicio". A pátria está relacionada mais ao governo e à Grande Junta que ao território.

\footnotetext{
${ }^{55}$ Gazeta de Buenos-Ayres número 34, 31 de janeiro de 1811, p. 3.

${ }^{56}$ Ibidem, p. 4-5.
} 
Os dois termos destacados possuem acepções diferentes daquelas que possuíam durante o Antigo Regime. Também percebemos que esses novos significados já se espalhavam pela sociedade, ainda que não totalmente, já que uma carta não pode exemplificar o todo da sociedade. As novas acepções criadas durante essa nova experimentação política encontravam espaços nas falas de certos grupos de pessoas.

Logo na edição seguinte, o periódico publicou um manifesto dos editores, uma proclamação da Junta Governativa e uma proclamação do Cabildo de Buenos Aires. Todos sobre a nomeação de D. Francisco Xavier Elio como Vice-rei do Prata. Os editores da Gazeta afirmavam que o mundo inteiro descobriria que a Regência e o Vice-rei possuiam: "um proyecto concertado de convertir esta capital en una masmorra de esclavos, admirará este acontecimento como el ultimo arrojo de los tiranos. ${ }^{, 57} \mathrm{O}$ texto segue com uma critica à escolha feita pela Regência:

"Vease aqui ya descubierto el origen de ese escandaloso vireynato, com que el gobierno español acaba de premiar la enconada rabia de Elio, y la prueba mas autentica de descalabrado manejo. La precision, en que hallaba de ser justo para con la América, debió hacerlo prudente y advertido. De poner sua inflexibilidad quando no convenia si moderacion, y esperar de la politica y el tiempo el remedio de unos males, que la violência debia irritar, era todo lo que dictaba la prudencia. Pero el gobierno de España destinado a perderlo todo, elige siempre lo peor.(...)

A vista de esto ¿que valor deberemos dar á esas magnificas declaraciones de igualdad, de ciudadanía, de libertad y proteccion contral la tirania de los que mandam? ",58 (negrito meu)

Novamente termos "igualdad", "ciudadania" e "libertad" apresentados com caráter político, pois estão atrelados ao discurso da Regência de autonomia e igualdade entre a metrópole (Espanha) e a América Espanhola. Após este manifesto temos uma proclamação da Junta Grande onde se diz aos portenhos que havia uma possibilidade de ataque, por parte do novo Vice-rei, contra a cidade e que eles deveriam resistir ao despotismo e à tirania.

"Siguiendo los impetus de su fogosidade indiscreta creemos que tendrá el atrevimiento de intentar atacarnos(...)

\footnotetext{
${ }^{57}$ Gazeta de Buenos-Ayres número 35, 07 de fevereiro de 1811, p. 2.

${ }^{58}$ Ibidem, p. 4-5.
} 
Porteños, ved en este hecho el desprecio con que os mira, disponeos á esçarmentar ese infatuado orgullo, y que aprenda á su costa á temeros y respetaros: aprenda el corrompido gobierno de la Regencia que á governar pueblos libres no se destinan canibales: tiemblen con la idea de nuestro enojo;" 59

Por fim, o Cabildo de Buenos Aires publica um manifesto sobre o mesmo assunto.

"Distinguido vecindario ,aguerrida guarnicion, ilustres hijos de Buenos Ayres: ya habeis visto las iniciativas que hace el mariscal de campo D. Francisco Xavier de Elio para que se le ponga em posesion del superior mando de estas provincias, que expresa habersele conferido por el Consejo de Regencia: Tambien estais instruidos de lo que oficialmente se la insinuado la contestacion. Si en ésta luce la moderacion em concurso con la dignidad, es solamente por lo que se debe á sí mismo este pueblo siempre circunspecto, magestuoso y prudente. Otro que le fuera menos, á mas de los convecimientos apuntados para justificar la inadmision de Elio, la hubiera tambien fundado en la absoluta desorganizacion del actual gobierno español, cuyo concepto lo induce necesariamente el mero hecho de haberse decidido á uma eleccion tan antipolitica por todas sus circunstancias: hubiera desconfiado de la realidad de esos sentimientos de equidad y beneficiencia hácia las Américas, de que hace alarde el gobierno peninsular, pues em los momentos precisos en que proclama la igualdad de derechos de los pueblos del nuevo mundo com los da metrópoli, envia quien los gobierne baxo el mismo sistema..." ${ }^{60}$ (negrito meu)

Nas citações acima podemos ver o termo "pueblo" escrito de duas formas e com dois sentidos diferentes, o que demonstra a polissemia do conceito. Por duas vezes o termo aparece no plural em um sentido territorial-municipalista: "pueblos libres" e "pueblos del nuevo mundo". Mas também aparece o termo "pueblo" no singular e seu sentido é político, uma vez que ele é o depositário da soberania. Acepção esta forjada pelo próprio Cabildo durante as discussões da Revolução de Maio que colocavam no poder a Junta Provisória, de caráter autônomo em relação as decisões do Conselho de Regência.

Com a negação da Junta em aceitar Elio como Vice-Rei e retornar o governo das províncias ao modelo colonial, Montevidéu declarou guerra a Buenos Aires. Analisemos um trecho da declaração de guerra do Vice-Rei Francisco Xavier Elio à Junta de Governo de Buenos Aires, na qual o primeiro chama a segunda de traidora e rebelde:

\footnotetext{
${ }^{59}$ Ibidem, p. 6.

${ }^{60}$ Ibidem, p. 7.
} 
"Hago a saber todos os los vasallos de Fernando VII, que habiendo tentado por quantos medios sugiere la prudencia,y dicta la humanidad para hacer entrar sus deberes y obligaciones á los componen la Junta de Buenos-Ayres, que se há abrogado el gobierno superior de todo el vireynato, han despreciado to arbitrio político, y de conciliacion; despues de haber dado principio á su mando con tiranias, y muertes a los xefes principales de la provincia, sin guardar la menor formalidad, ni tramite judicial (...) llegando su osadía, despues de una larga série de insultos, provociones y amenazas, al extremo de insultar al Consejo de Regencia, que en nombre de nuetro amado Fernando VII manda la España y las Indias, y esta reconocido por todas las potencias de la Europa; usando con felonia del augusto nombre de nuestro desgraciado Monarca, para solapar con él las miras de ambicion é infamia que ocultan. Por tanto, y en uso de las facultades, que el Rey me concede, y me autoriza la ley como virey y capitan general del reyno, declaro en nombre de nuestro augusto Soberano el Sr D. Fernando VII, y la nacion, por rebelde y revolucionario el expresado actual tiránico gobierno de Buenos Ayres. Que los individuos que los componen, y todos los que lleven armas ú otros útiles de guerra para sosternerla, y atacar la obras baxo la verdadera divisa del estandarte del Rey de España, sean tenidos por traidores, y rebeldes á su Rey y á la Patria, y cmo tales tratados y juzgados;" ${ }^{1}$

Agora nos debrucemos sobre os seguintes trechos da Proclamação da Junta em resposta a declaração do Vice-Rei:

"Hace algun tiempo que la voluntad general de los pueblos por ser líbres se halla pronunciada del modo mas solemne y expressivo. Ministros del despotismo mas fiero, cuyas concusiones y rapinas vexaban nuestras fortunas á pretexto de asegurar á la España sus derechos, pretendian tenernos siempre agobiados baxo el peso enorme de su yugo, y marcados publicamente con el sello de la esclavitud... La España, ya lo sabeis, en sus últimas agonias acaba de legar al mariscal de campo D. Francisco Xavier Elio su espíritu de tirania. Hecho virey de estas provincias este hombre arrebatado, y auxiliado de los rebeldes europeos de la orgullosa Montevideo, ha tenido la insolencia de declararnos la guerra, y pretende inundar en sangre estas provincias, que debia respetar como el mejor asilo de la fugitiva libertad... A vosotros ciudadanos de Buenos Ayres os estan reservados los primeros golpes, igualmente que la gloria de haberlos dado. Á vosotros a dexado la providencia la alternativa de ser el mas digno pueblo de la América del Sud, siendo los libertadores de ella, o el primero de los esclavos. A vosotros como á todos los demas del vireynato os excitamos á las armas. La necesidad exige que los pueblos en massa empuñen vigorosamente las armas: ellas serán em las manos robustas de los defensores de la pátria, los instrumentos decisivos de la victoria... Sean vuestros brazos los fiadores de vuestra independencia. Vale mas mas sacrificar nuestras vidas y nuestros bienes á la libertad de la patria, que reservarlos para despojos de nuestros opresores. Vale mas combatir pela independencia de la nacion, que servir de víctima á los caprichos de um tirano." 62

\footnotetext{
${ }^{61}$ Gazeta de Buenos-Ayres número 41, 21 de março de 1811, p. 6-7.

${ }^{62}$ Ibidem, p. 10-12.
} 
Na resposta da Junta temos a utilização do termo "independencia”, como a separação definitiva da metrópole espanhola, algo que até então não havia aparecido nos textos produzidos pela Junta que sempre se dizia autônoma, mas fiel à Coroa. Também podemos perceber a utilização de pátria referindo-se ao governo da Junta de Buenos Aires. Com a mesma acepção encontramos o termo nação, o que contrapondo-se ao sentido mais comum que se referia ao Império Espanhol no todo.

Veremos agora de que forma José Artigas general das tropas da Junta na Banda Oriental se direciona aos seus comandados:

"Leales y esforzados compatriotas de la Banda Oriental de Rio de la Plata: vuestro heroyco entusiasmado patriotismo ocupa el primer lugar en las elevadas atenciones de la Excma. Junta de Buenos Ayres, que tan dignamente nos regenta. Esta, movida del alto concepto de vuestra felicidad, os dirige todo los auxilios necesarios para perfeccionar la grande obra que habeis empezado; y que continuando con la heroycidad, que es análoga a vuestros honrados sentimientos, extermineis á esos genios díscolos opresores de nuestro suelo, y refractarios de los derechos de vuestra respetable sociedad (...) Para conseguir el feliz éxito, y la deseada felicidad á que aspiramos, os recomiendo á nombre de la Excma. Junta vuestra protectora, y en el de nuestro amado xefe, una union fraternal, y ciego obedecimiento á las superióres oredenes de los xefes, que os viene a preparar laureles inmortales. Union, caros compatriotas, y estad seguros de la victoria. Hé convocado á todos los patriotas caracterizados de la campaña; y todos, todo se ofrecen con sus personas y bienes, á contribuir á la defensa de nuestra justa causa. = A la empresa compatriotas, que el triunfo es nuestro: vencer ó morir sea nuestra cifra; y tiemblen esos tiranos de haber excitado vuestro enojo, sin advertir, que los americanos del sud, están dispuestos á defender sú patria; y a morir antes con honor, que vivir con ignominia en afrentoso cautiverio. "

Vemos como Artigas exalta a Junta Provisória quando a chama de protetora e digna, e como convoca seus homens à cega obediência e à morte antes de voltarem a serem cativos de um regime tirano representado pelo Conselho de Regência na figura do Vice-Rei Ellio.

A seguir temos uma carta endereçada à Junta por Artigas e José Rondeau, os generais da Banda Oriental, na qual pediam a proteção contra as calúnias que os lideres das tropas estariam recebendo.

"Habiendo trascendido, que con notable ofensa de la buena armonia, union, y amistad que observamos los generales de esto exército, se han esparcido noticias contrarias; hemos acordado dar á V.E. un testimonio de la inalterable unidad, que

${ }^{63}$ Gazeta de Buenos-Ayres número 48, 09 de maio de 1811, p. 3-4. 
ciñe nuetras operaciones, en todo conformes con los interéses de la patria. Los generales del exército Oriental, en quienes V.E. ha depositado las armas de la patria, hemos militado juntos antes de ahora; y podemos asegurar á V.E., con toda la ingenuidad que nos caracteriza, que desde nuestras primeras relaciones, ha sido reciproca nuestra simpática comunicacion. Una mutua correspondencia entre ambos, ha cimentado nuestra amistad síncera; y la alta confianza que debemos á esta Excma. Junta, ha sido un nuevo material para consolidarla mas. Nuestras providencias, sobre las operaciones militares del exército, son unas, y el objeto que las rige, es la ansiada libertad de nuestra madre patria: á esta dedicamos todos nuestros conatos, y fatigas, hasta sacrificar nuestras vidas en su defensa: todos los oficiales, que tenemos el honor de mandar, respiran iguales sentimientos, $y$ son tan unidos en el desempeño de su ministerio, como joviales en su trato familiar. En esta virtud esperamos, que V.E. nos haga el honor de disipar qualquiera otra equívoca especie; dignandose admitir este rasgo de nuestra sinceridad, como el mas seguro garante de nuestra inalterable union, y de la afeccion con que somos de V.E. con mayor respeto.

Dios guarde V.E. muchos años. Quartel general del Arroyo Seco 8 de setiembre de $1811=$ José Rondeau= José Artigas = Excma. Junta Gubernativa de las provincias del Rio de la Plata",64

Foi no Rio de Janeiro, em 20 de outubro de 1811, onde ocorreram as negociações para uma solução para a guerra. Foi sob a liderança do britânico, Lord Strangford ,que finalmente ficou acordada a restauração da paz entre os governos de Buenos Aires e Montevidéu, deixando em suspenso a disputa entre os “juntistas portenhos" e "regentistas montevideanos”. A participação da Inglaterra nas discussões de paz não foi por acaso, já que esta queria manter o livre comércio na região garantido para os comerciantes britânicos, de forma que pudesse ser desenvolvido o tráfego comercial, sem surpresas ou problemas para estes.

\subsection{Liberdade}

Tema sensível à Revolução Francesa, a liberdade também teve espaço de discussão na Gazeta de Buenos-Ayres. A seguir temos um trecho do editorial escrito por Agrelo intitulado "DE LA LIBERTAD”.

“'Léjos de nosotros este error, que una licencia extremada llama libertad! Ella es precisamente su contraria. La verdadera es el primer don del cielo, el derecho mas sagrado de la humanidad, y el primer gérmen de la virtud y del bien: á su voz corren á la guerra los mismos instrumentos de paz. La imágen de la libertad oprimida es la que, rompiendo dificultades, animó á este gran pueblo á colocar á su frente un gobierno capaz de restituir la fuerza y vigor de que carecia el cuerpo político. (...) La libertad es la que gobierna la voluntad de los individuos con respecto al interes y voluntad del cuerpo social conocida y manisfestada por

\footnotetext{
${ }^{64}$ Gazeta de Buenos-Ayres número 67, 19 de setembro de 1811, p. 1-2.
} 
las leyes: la licencia es la que somete á los cobardes al imperio de las pasiones particulares: aquella es la base de la libertad pública, y el fin principal de todo gobierno justo, esta enerva el alma y se aproxima al despotismo (...)

Una fatalidad, ó mas bien la poca ilustracion imprescindible de un estado nasciente, ha hecho comprender la palabra libertad en un sentido absoluto; es decir, que aunque la libertad sea la facultad de hacer quanto no esté prohibido por la ley, la que nada debe prohibir sino aquello en que el hombre prejudica al hombre, no obstante esta facultad, debe todo ciudadano que vive en sociedad someterse á una infinidad de leyes indispensables al bien general. Por eso esta definicion no se debe tomar en un sentido absoluto, sino comparativamente con su contrario el despotismo; es decir, que el hombre que vive en sociedad no goza de ninguna especie de libertad absoluta; porque sus mas pequeñas acciones están en entera dependencia de las leyes e de la opinion. (...)

De aquí resulta que no conviene hablar al pueblo por principios tan abstractos y generales, que pueden inducir en error, sino por lo mas palpable, que debe comprehenderse en esta regra: TODO GOBIERNO DESPÓTICO ES NULO. Llámase gobierno despótico el que en nada depende de la nacion á quien manda. El modo de hacer que el gobierno dependa de la nacion, sin que le se quiten la facultades necesarias para dirigirla, es que todo ciudadano tenga derecho á concurrir á la eleccion de sus representantes, para que estos formen y califiquen las leyes que todos han de obedecer, segun les comprehendan. "65

Percebemos que para o editor, a liberdade é apresentada como o direito mais sagrado da Humanidade, mas deveria ser regulada por leis. É a partir das leis que o bem geral pode ser mantido e a sociedade organizada. Assim um governo que não desejasse ser despótico necessitava da Nação, permitindo que todo cidadão pudesse concorrer à eleição de seus representantes para que estes pudessem criar as leis que todos deveriam seguir para alcançar o bem geral.

Vejamos o Vicente Pazos tem a dizer sobre o mesmo tema:

"El objeto, y el interés de todo gobierno deben ser mantener la armonía de la sociedad establecida, sobre las relaciones morales de la justicia y del órden fisico, y proteger a todos los que componen esta sociedad. La reunion de la voluntad de todos en uma ó varias personas nace sin duda del convencimiento que hay de la utilidad de obedecer.(...)

Como el fin de los periódicos es generalizar las ideas, consolidar la opinion por la repeticion de las materias politicas; hé creido conveniente tratar de la libertad, porque la suerte de las gazetas es, ser arrojadas inmediatamente que hayan ministrado las noticias. Los que estamos encargados á disipar, segun nuestras fuerzas, las nubes con que se quieren ofuscar á nuestros compatriotas, para que desconozcan sus verdaderos interéses, debemos fixar para siempre el sentido recto de unas voces, que mal entendidas, ó debilmente olvidadas, serían indicio infalible de nuestra ruina.

No hay delirio igual al de confundir la libertad con el desorden. En ningun tiempo gozan de menos libertad los hombres, que quando no conocen freno alguno. Finjase un pueblo en que cada qual pudiese obrar segun su capricho: los

\footnotetext{
${ }^{65}$ Gazeta de Buenos-Ayres número 70, 10 de outubro de 1811, p. 2-4.
} 
mas iniquos, los mas fuertes serían de algun modo libres; los buenos, los débiles estarían reducidos a ser sus esclavos. Por eso de la licencia, y desenfreno de un pueblo nace infaliblemente la tiranía.(...)

La libertad política consiste en que una nacion solo esté sujeta á las leyes, que de su grado haya conocido. Esta libertad general no vive sino á costa de sacrificios de la libertad de cada uno. Se engaña torpemente el que juzgue, que los claman por vivir en un gobierno libre, quieren vivir mas á sus anchas. ${ }^{, 66}$

Observasse que os dois editores pensavam a mesma coisa sobre a liberdade: ela não poderia existir sem leis que resguardassem o bem geral. Para viver em sociedade cada um deveria estar disposto a abrir mão de liberdades individuais para que a ordem social fosse mantida. Os dois editais, aqui apresentados, deixam clara a grande influência iluminista que estes escritores tiveram e como estas ideias também faziam parte da proposta de governo para a região do Prata.

Uma das medidas tomadas pelo Triunvirato ao chegar ao poder foi elaborar um decreto sobre a liberdade de imprensa. No ofício escrito o governo afirmava que era necessário “(...)restituir á los pueblos americanos, por meio de la libertad politica de la Imprenta, ese precioso derecho de la naturaleza (...)" ${ }^{, 67}$, pois este direito não era respeitado anteriormente e assim "el pueblo" poderia expressar-se e formar a opinião pública.

Do decreto podemos destacar os seguintes artigos:

"Artículo $1^{\circ}$

Todo hombre puede publicar sus ideas libremente, y sin previa censura. Las disposiciones contrarias á esta libertad, quedan sin efecto.

Articulo $2^{\circ}$

El abuso de esta libertad es un crimen. Su acusacion corresponde á los interesados, si ofende derechos particulares; y á todos los ciudadanos, si compromete la tranquilidad pública, la conservacion de la religion católica, ó la constitucion del estado. Las autoridades respectivas impondrán el castigo segun las leyes. "68

Vejamos como esse decreto foi recebido nas palavras de um dos leitores da Gazeta, que questiona essa nova lei:

\footnotetext{
${ }^{66}$ Gazeta de Buenos-Ayres número 01, 05 de novembro de 1811, p. 1.

${ }^{67}$ Gazeta Extraordinaria de Buenos-Ayres, 26 de outubro de 1811, p.2.

${ }^{68}$ Idem
} 
"Sr. Editor. Muy Sr. Mio: quando se anunció la libertad de la prensa, desnuda de las trabas con que anteriormente se habia publicado, crei seguramente que el decreto último correspondiesse a mis deseos porque está probado que este es uno de los remedios para rectificar, y moderar los gobiernos, vulgarizar conocimientos utilies, aclarar opiniones, ó verdades, que sin esta facilidad jamas se consiguiria; y si la libertad politica de la imprenta es para publicar libremente las ideas, debe ser en todos los ramos politicos: es decir, que no siendo doctrinas que toquen al dogma, se puede hablar de los abusos, y defectos del gobierno, de su inercia, de su ignorancia, de las reformas politicas y económicas de todas as clases; y de la forma de gobierno que sea mas conveniente o analoga a las provincias del Rio de la Plata, ó á toda la América en general. Yo señor mio, entiendo, que todos estos ramos deben estar sujetos á la inquisicion de los literatos, y hombres expertos que quieren filosofar, y politicar.

Por este principio, me parece indefinido el artículo segundo del reglamento publicado: en él se sanciona que será un crimen atacar la constitucion del estado, y comprometer la tranquilidad pública. Por constitucion de estado creo deberá entenderse la constitucion monarquica española, porque no tenemos otra. Ahora bien, el que la impugne como un codigo que no tiene fuerza porque no esta legitimamente reconocido por la América, y talvez por la nacion española; el que pruebe que son unas leyes arbitrarias degradantes a todos los americanos, principalmente las leyes de Indias ¿atacara la constitucion? El que dixe e que no hubo contrato ni pacto social, que es el que debe obligar á las partes del cuerpo politico ¿cometeria un crimen? Si reside obrigatoriamente en el pueblo la soberania, el que dixese, señor V.M. puede, y debe variar, mudar, y establecer la constitucion conforme mas le convenga ¿atacaría este la constitucion del estado?(...)

Igualmente comprometer la tranquilidad pública por impresos, será excitando á rebelion, asonada ó tumulto; si los papeles ó impresos inducen á este crimen, no hay duda que comprometen la tranquilidad publica; pero se manifestan los defectos de los individuos del gobierno en sú conducta pública, si descubren la mala intencion y abuso del poder que se le has confiado; porque muchos abusando de la autoridad, se llamaban tambien costituidos: en este caso ¿seria comprometer la tranquilidad pública?",69

As dúvidas levantadas na carta colocavam em cheque a ideia de liberdade de imprensa que o Triunvirato possuía. Como se poderia ter liberdade se não era permitido falar contra as instituições que formavam o governo ou contra seus membros. Onde estava essa liberdade na lei?

Assim respondeu o periódico à carta de El Ciudadano libre.

"Muy señor mio: no se equivoca vmd. quando juzga, que si la libertad de la imprenta tiene por objeto la libre publicacion de ideias en toda clase de asuntos politicos, debe ser permitido al ciudadano hablar de los abusos y defectos del gobierno, de su inercia, de su ignorancia, de las reformas políticas y económicas, y de la forma de gobierno que sea mas conveniente, ó análoga á las provincias del Rio de la Plata, ó á toda la América en general; pero no puedo comprender la conexion de este antecedente con las consecuencias que vmd. deduces, ó por mejor

\footnotetext{
${ }^{69}$ Gazeta de Buenos-Ayres número 02, 08 de Novembro de 1811, p. 4.
} 
decir, como pueda aguirse de esto principio lo indefinido del articulo segundo del reglamento de la libertad política de la imprenta. (...) Dice vmd. muy bien, que no siendo lícito atacar la constitucio del estado, deberá consiguientemente respertarse la constitucion monarquica española; pero de aqui no se sigue ni remotamente que será un crimen escribir contra los errores, ó el despotismo de las leyes; porque ni los estatutos reglamentados ni las leyes municipales, ni esa acumulacion de ordenaciones, creadas por la arbitrariedad, y la tiranía en la obscuridad del gabinete son la constitucion nacional. Solamente aquellas disposiciones que sancionaron, ó recibieron todos lo pueblos como el vínculo, ó el fundamento: de la unidad nacional es lo que segun yo entiendo, debe llamarse constitucion. (...)

No digo por esto que las leyes fundamentales son eternas; no señor; elas pueden variarse por los mismos pueblos que las establecieron, porque nadie puede negar á las naciones la facultad de dar las formas que quieren á sus gobiernos, y cambiar quando gusten las bases del pacto social: pero entretanto no es licito concitar a los ciudadanos, para que desconozcan un principio que asegure la unidad nacional.

Lo mesmo digo con respecto á las dificultades que vmd. propone sobre el compromiso de la tranquilidad pública. Rebelar los pueblos contra las autoridades, tumultuarlos contra el gobierno que han reconocido, sería ciertamente un delito contra el sosiego, y la seguridad pública: pero manifestar los vicios de su constitucion, la ignorancia, la falta de actividad, y en una palabra atacar los defectos de la conduta oficial de los que gobiernan, y los errores de sus providencias, esto tan lejos de ser crímen en un beneficio, que se rinde á la causa sagrada de los pueblos, y una barrera contra los embates de la ambicion. ",70

Podemos perceber nas palavras do editor, uma esperada defesa ao projeto, pois a Gazeta era um instrumento do Governo. Para tranquilizar o remetente da carta afirma que seriam permitidas críticas ao Governo, desde que essas não pusessem em perigo a segurança pública, e para tanto foi criado um órgão para fiscalização e punição para os casos de infração ao decreto. Esse órgão é um mecanismo de censura criado pelo Triunvirato, fato veementemente negado pela Gazeta, para impedir que discursos de oposição ao Governo circulassem pela região do Prata e impelisse um debate que pudesse levar a uma revolta contra os que estavam no poder.

\footnotetext{
${ }^{70}$ Gazeta de Buenos-Ayres número 03, 12 de novembro de 1811, p. 2-3
} 


\section{4 \\ Conclusão}

Este trabalho propôs uma indagação sobre os valores conferidos à época a alguns termos da linguagem política e social utilizada no processo de independência da cidade de Buenos Aires, em especial os vocábulos "autonomia" e "soberania".

O objetivo foi analisar quais os valores conferidos a ambos como parte da linguagem política e social utilizada pela "Gazeta de Buenos-Ayres" entre os anos de 1810 e 1812, pensando como estes termos aparecem no periódico. E como estes se transformaram e se adaptaram àquela conjuntura, influenciando e, simultaneamente, sendo influenciados pelas transformações políticas em curso.

Assim buscou-se analisar na região coberta pela "Gazeta de Buenos-Ayres" ,neste período, se os sentidos destes vocábulos eram coincidentes ou se já começavam a se diferenciar significativamente daqueles sentidos anteriores mais amplamente utilizados durante o Antigo Regime.

Vimos durante o trabalho que não se pode falar destes dois conceitos (autonomia e soberania) sem analisar e refletir sobre outros tantos como: “patria”, "nación”, "Pueblo/pueblo/pueblos" e "libertad”. Todos estes sofreram alguma transformação no curso desses dois anos de novas experimentações políticas na região do Prata influenciando uns aos outros.

Se antes da Revolução de Maio, a soberania estava ligada à figura do Rei e ao Trono do Império Espanhol, esta passa às mãos da sociedade que tem o poder de decidir a forma como quer ser governada. No caso portenho primeiramente pela Junta Governativa, que tornou-se Junta Grande e, posteriormente, Triunvirato.

O conceito de autonomia é mais emblemático que o de soberania, pois só irá ser tipificado no dicionário da Real Academia Española em 1835, com o sentido que possuí hoje, isto é, como sinônimo de independência. Para os cidadãos do Prata, no início do século XIX, autonomia era governar em nome de D. Fernado VII enquanto este estivesse preso por Napoleão. Em 1811 podemos 
ver que, embora ainda defendessem a figura do Rei, os portenhos preferiam a independência do Império Espanhol a voltar a serem governados de forma despótica.

A Gazeta tem um papel importante nessas transformações, ainda que saibamos que naquele período os que sabiam ler eram poucos. O periódico é um importante campo de debates e embates, e formador de opinião mesmo que para um pequeno grupo da população. Importante também, neste sentido, foi ser o periódico oficial do governo, o que lhe permitiu uma longevidade fora do comum, comparado a outros títulos da mesma época.

Podemos concluir que as transformações sofridas pelos conceitos autonomia e soberania durante os anos de 1811 e 1812 estiveram diretamente ligadas às rápidas mudanças políticas do período e às novas experiências de cidadania vividas por aqueles homens nesse contexto de revoluções políticas. Não podemos dizer que a Gazeta teve papel principal nas transformações destes conceitos na região, mas sem dúvida, um papel de extrema importância como veículo de escritos e ideias, principalmente aquelas relacionadas à governança das províncias e à politica do Estado em formação no período, permitindo assim, a médio prazo, a criação de uma opinião pública e de um espaço de debate para a sociedade portenha. 
Fontes

Actas capitulares desde el 21 hasta el 25 de Mayo de 1810, en Buenos Aires.

Constitucion Política de la Monarquía Española. Cádiz: Imprenta Real, 1812. p. 7

Diccionario de la Real Academia Española. Diccionario de la lengua castellana compuesto por la Real Academia Española, reducido a un tomo para su más fácil uso. Quarta edición. Madrid: Viuda de Ibarra, 1803.

Diccionario de la Real Academia Española. Diccionario de la lengua castellana por la Real Academia Española. Undécima edición. Madrid: Imprenta de Don Manuel Rivadeneyra, 1869.

Gazeta de Buenos-Ayres, 1811-1812. Buenos Aires: Imprenta de Niños Expósitos.

Orden de Santiago de Liniers y Bremond para la convocatoria de las Milicias Urbanas, 09 de Setembro de 1806

Proclama de Santiago de Liniers y Bremond para la creación de los Cuerpos Urbanos destinados a la defensa de Buenos Aires, 06 de Setembro de 1806. 
6

Referências Bibliográficas

ACEVEDO, Edberto Óscar. La Independencia Argentina. Madrid: Editorial MAPFRE, 1992.

CAILLET-BOIS, Ricardo $R$. Estatutos, reglamentos y constituciones argentinas 1811-1898. Buenos Aires: Universidad de Buenos Aires, 1956. 244 p.

CANSANELLO, Oreste Carlos. Ciudadano. Argentina - Río de la Plata. In: SEBASTIÁN, Javier Fernández (Org.). Diccionario político y social del mundo iberoamericano. La era de las revoluciones, 1750-1850. Madrid: Fundación Carolina, Sociedad Estatal de Conmemoraciones Culturales, Centro de Estudios Políticos y Constitucionales, 2009, p. 199.

CHIARAMONTE, José Carlos. Ciudades, provincias, Estados: Orígenes de la Nación Argentina (1800-1846). Buenos Aires: Editora Espasa Calpe Argentina, 1997. 645 p.

. La formación de los Estados nacionales em Iberoamérica. Boletín del Instituto de Historia Argentina y Americana "Dr. Emilio Ravignani", Buenos Aires, v. 3, n. 15, p. 143165, jan.-jul. 1997.

Nación y Estado en Iberoamérica. El lenguaje político en tiempos de las independencias. Buenos Aires: Sudamericana, 2004. 224 p.

CORBELINNI, Enrique. La Revolución de Mayo Tomo II. Buenos Aires: Lajouane, 1950. p. 20.

DONGHI, Tulio Halperin. História da América Latina. Rio de Janeiro: Paz e Terra, 1975. 323 p. 
Politics Economics and Society in Argentina

in the Revolutionary Period. Londres: Cambridge University Press, 1975. $425 \mathrm{p}$.

GOLDMAN, Noemi (Org.). Revolución, república, confederación: 18061852. Buenos Aires: Sudamérica, 2005.

GOLDMAN, Noemi; MEGLIO, Gabriel Di. Pueblo. Argentina - Río de la Plata. In: SEBASTIÁN, Javier Fernández (Org.). Diccionario político y social del mundo iberoamericano. La era de las revoluciones, 17501850. Madrid: Fundación Carolina, Sociedad Estatal de Conmemoraciones Culturales, Centro de Estudios Políticos y Constitucionales, 2009, p. 1151-1162.

LYNCH, Jonh. As Origens da Independência da América Espanhola. In: BETHELL, Leslie (org.). História da América Latina: Da Independência até 1870. São Paulo: Editora da Universidade de São Paulo; Brasília: Fundação Alexandre de Gusmão, 2004. p. 19-72.

MATURANA, Antonio Calvo. "La revolución de los españoles en Aranjuez": el mito del 19 de marzo hasta la Constitución de Cádiz. Cuadernos de Historia Moderna, Madri, n. 11, p. 145-164, 2012.

PAMPLONA, Marco A. Comentários sobre las independencias y la creación de Estados Nación en América Ibérica: um abordaje comparado entre la América portuguesa y la América hispánica. In: QUIRÓS, Pilar Gonzáles Bernaldo de (Org.). Independencias Iberoamericanas: Nuevos problemas y aproximaciones. Buenos Aires: Fondo de Cultura Economica, 2015. p. 87-103.

PIMENTA, João Paulo. Estado e Nação no fim dos impérios ibéricos no Prata (1808-1828). São Paulo: Hucitec, 2006.

SEBASTIÁN, Javier Fernández (Org.). Diccionario político y social del mundo iberoamericano. La era de las revoluciones, 1750-1850. Madrid: Fundación Carolina, Sociedad Estatal de Conmemoraciones Culturales, Centro de Estudios Políticos y Constitucionales, 2009. 